\title{
The DeAN WhO WeNT TO LAW SCHOOL: Crossing Borders ANd SEARChING FOR PURPOSE IN NORTH AMERICAN LEGAL EDUCATION, 1930-1950
}

\author{
ERIC M. ADAMS*
}

\begin{abstract}
This article is about the making of modern legal education in North America. It is a case study of the lives of two law schools, the University of Alberta, Faculty of Law and the University of Minnesota Law School, and their respective deans, Wilbur Bowker and Everett Fraser, in the decades surrounding the Second World War. The article follows Bowker's unorthodox route to Alberta's deanship via his graduate training under the experimental "Minnesota Plan" - Fraser's long-forgotten effort to place public service at the centre of American legal education. In detailing an overlooked moment of transition and soulsearching in North American legal education, this article underlines the personalities, ideologies, circumstances, and practices that combined to forge the still dominant model of university-based legal education across the continent. Highlighting the movement of people and ideas, this study corrects a tendency to understand the history of law schools as the story of single institutions and isolated visionaries. It also reveals the dynamic ways in which law schools absorbed and refracted the period's ideological and political concerns into teaching practices and institutional arrangements. In bold experiment and innate conservatism, personal ambition and institutional constraints, and, above all else, faith in the power of law and lawyers, the postwar law school was born.
\end{abstract}

\section{TABLE OF CONTENTS}

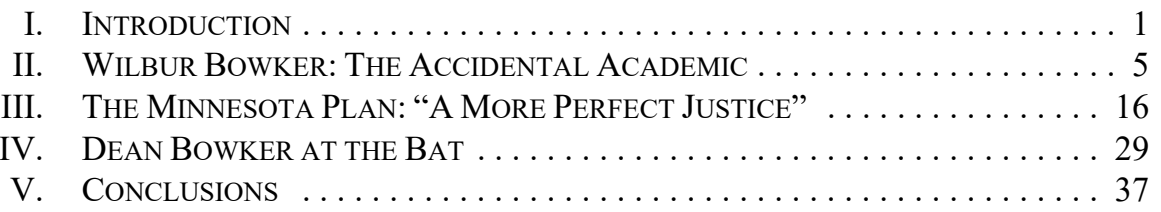

\section{INTRODUCTION}

"We are in a bad way here," George Steer, Acting Dean of the University of Alberta, Faculty of Law, lamented in November 1946. "What we need," he pleaded to law deans across the country, "is some young man, from 25 to 35 years of age, of good mental caliber, who wants to make teaching his job." The replies were not encouraging. "I sympathize with your cry of distress," Cecil (Caesar) Wright, Dean of Osgoode Hall, answered. "To be quite

Associate Professor of Law, University of Alberta, Faculty of Law. An earlier version of this article received the 2014 Canadian Association of Law Teachers'Scholarly Paper Award. This research was supported by the Alberta Institute for American Studies, the Centre for Constitutional Studies, and the Faculty of Law, all of the University of Alberta, and the able research assistance of Daniel Girard, Kelsey Robertson, Sarah Hamill, and Jacqueline Byers. Earlier versions of this work were presented at the University of Alberta, Faculty of Law, the Toronto Legal History Workshop, and the 2014 Annual Meetings of the Law and Society Association. I thank audiences for helpful feedback. I also thank two anonymous peer reviewers, and John Law and Anna Lund for valuable constructive criticism. David Percy, Trevor Anderson, Judge Allan Lefever, and the Right Honourable Madam Justice Beverly McLachlin very generously shared their memories of Wilbur Bowker with me. Finally, this article is for Bruce Ziff.

1 Steer to Wright (25 November 1946), Toronto, University of Toronto Archives (B1982-0028, Box 2, Wright Papers). 
frank, I don't think that I could be of any possible assistance, because the number of persons who might be interested in work of this kind is, so far as I know, absolutely nil.",2

The University of Alberta, Faculty of Law was in trouble and Steer, the hard-nosed Edmonton litigator temporarily in charge, knew it. Law student numbers had dwindled to fewer than ten in all three years combined. ${ }^{3}$ Talk within the profession swirled about merging law schools to conserve resources. ${ }^{4}$ The Faculty's pioneering dean, John Weir, had died unexpectedly in 1942 after leading the Faculty since its founding as a full-time program in 1921. ${ }^{5}$ His replacement, Malcolm MacIntyre, had returned to his home in New Brunswick and requested permanent leave from the University a few weeks before the start of term in 1945. After a series of high profile candidates turned down the deanship - George Curtis opted to become the founding dean at the University of British Columbia's Faculty of Law, Vincent Macdonald remained at Dalhousie after learning of Alberta's small operating budget, and a February visit could not convince Horace Read to leave the Minnesota Law School the University eventually offered the position on an interim basis to Wilbur Bowker, the local lawyer who had already been hired to teach most of its classes. A problem remained, however, especially for an institution still eager to solidify its scholarly reputation as a serious academic institution: Bowker possessed no graduate degree. And so in the summer of 1946 — with veterans returning to law schools across North America — Professor Bowker rattled across the prairies by train to enrol at the University of Minnesota Law School.

Although Bowker crossed a border in search of a graduate degree, he discovered a law school searching for a new purpose in legal education. Bowker's journey, and that of the University of Minnesota Law School alongside it, is the story of the making of modern North American legal education. This article examines the forces and circumstances - intellectual, personal, social, and political - that came to shape and define North American universitybased law schools. It does so by tracing the connected history of two institutions (the University of Alberta, Faculty of Law and the University of Minnesota Law School), and their border-crossing deans (Wilbur Bowker and the transplanted Canadian, Everett Fraser). Underappreciated, and indeed, largely unknown outside of their respective institutions, the deanships of Bowker and Fraser, and the institutions they led, shed light on the incorporation of public service rationales, public law offerings, and extra-legal perspectives into existing pedagogical and institutional frameworks of legal education.

Notwithstanding the dire pronouncement, Wright went on to suggest J.B. Milner, then on the faculty of Dalhousie Law School (Wright would hire him in 1950 to join the University of Toronto), and Maxwell Cohen at McGill. With a nod to the period's casual and prevalent anti-Semitism, he added that "Cohen is extremely able, although perhaps a little bumptious and of course, he is Jewish which may or may not affect your choice in Alberta." Wright to Steer (29 November 1946), Toronto, University of Toronto Archives (B1982-0028, Box 2, Wright Papers). In the fall of 1946 Cohen had just begun what would become a long and distinguished academic career at McGill, including serving as its dean. See William Kaplan \& Donald McRae, eds, Law, Policy, and International Justice: Essays in Honour of Maxwell Cohen (Montreal: McGill-Queen's University Press, 1993); R St J MacDonald, "Maxwell Cohen at Eighty: International Lawyer, Educator, and Judge" (1989) 27 Can YB Intl L 3. 
Although celebratory institutional law school histories remain common, important works in legal history have recognized that law schools - their deans, personnel, curricula, teaching practices, and cultures — are essential in understanding lawyers, the law, and legal culture alike. ${ }^{6}$ But gaps remain. The literature is dominated by studies of single institutions (usually celebrating a significant anniversary), eastern elite institutions have tended to draw a disproportionate amount of attention, ${ }^{7}$ and comparative work on relationships between institutions, especially across borders, is rare ${ }^{8}$ By contrast, this article tells a history of law professors and ideas about legal education crossing borders. Throughout, I draw upon two important insights when writing about the history of legal education. First, Laura Kalman reminds us of the need for attentiveness to the "institutional constraints" in which law schools operate - to accurately portray law schools and the ideas within them requires consideration not only of law professors and their writings, but also deans and University presidents, budgets and buildings, students and alumni. ${ }^{9}$ Law schools, like all institutions, are dynamic and plural places full of centrifugal contradictions and inconsistencies, as well as unifying trends and homogenizing influences. Where possible, this article attempts to embed the ideas of legal education in the realities of the teaching and administrative

The American literature is especially large, see generally William C Chase, The American Law School and the Rise of Administrative Government (Madison: University of Wisconsin Press, 1982); Robert Stevens, Law School: Legal Education in America from the 1850s to the 1980s (Chapel Hill: University of North Carolina Press, 1983); Laura Kalman, Legal Realism at Yale, 1927-1960 (Chapel Hill: University of North Carolina Press, 1986); John Henry Schlegel, American Legal Realism and Empirical Science (Chapel Hill: University of North Carolina Press, 1995) [Schlegel, American Legal Realism]; NEH Hull, Roscoe Pound and Karl Llewellyn: Searching for an American Jurisprudence (Chicago: University of Chicago Press, 1997). On Canadian legal education, see John PS McLaren, "The History of Legal Education in Common Law Canada" in Justice Roy J Matas \& Deborah J McCawley, eds, Legal Education in Canada: Reports and Background Papers of a National Conference on Legal Education Held in Winnipeg, Manitoba, October 23-26, 1985 (Montreal: Federation of Law Societies of Canada, 1987) 111; G Blaine Baker, "Legal Education in Upper Canada 1785-1889: The Law Society as Educator" in David H Flaherty, ed, Essays in the History of Canadian Law, Volume II (Toronto: University of Toronto Press, 1983) 49; W Wesley Pue, "Common Law Legal Education in Canada's Age of Light, Soap and Water" (1995) 23 Man LJ 654 [Pue, "Common Law Legal Education"]; David Howes, "The Origin and Demise of Legal Education in Quebec (or Hercules Bound)" (1989) 38 UNBLJ 127; Roderick A Macdonald, "The National Law Program at McGill: Origins, Establishment, Prospects" (1990) 13:1 Dal LJ 211; Peter M Sibenik, "Doorkeepers: Legal Education in the Territories and Alberta, 1885-1928" (1990) 13:1 Dal LJ 419; C Ian Kyer \& Jerome E Bickenbach, The Fiercest Debate: Cecil A. Wright, the Benchers, and Legal Education in Ontario, 1923-1957 (Toronto: Osgoode Society, 1987); AJ Hobbins, "Designating the Dean of Law: Legal Education at McGill University and the Montreal Corporate and Professional Elite, 1946-1950" (2004) 27:1 Dal LJ 163; John Willis, A History of Dalhousie Law School (Toronto: University of Toronto Press, 1979) [Willis, History of Dalhousie Law]; Sylvio Normand, Le droit comme discipline universitaire: Une histoire de la Faculté de droit de l'Université Laval (Saint-Nicolas: Presses de L'Université Laval, 2005); W Wesley Pue, Law School: The Story of Legal Education in British Columbia (Vancouver: University of British Columbia Faculty of Law, 1995) [Pue, Law School].

Wes Pue's critique that "developments in Alberta, Saskatchewan and Manitoba have not been incorporated into the 'general literature' on common law legal education in Canada" remains apposite: Pue, "Common Law Legal Education," ibid at 662.

$8 \quad$ But see Bernard J Hibbitts, "Our Arctic Brethren': Canadian Law and Lawyers as Portrayed in American Legal Periodicals, 1829-1911" in G Blaine Baker \& Jim Phillips, eds, Essays in the History of Canadian Law, vol 8 (Toronto: University of Toronto Press for The Osgoode Society for Canadian Legal History, 1999) 241; David M Rabban, Law's History: American Legal Thought and the Transatlantic Turn to History (Cambridge: Cambridge University Press, 2013); David Sugarman, "A Special Relationship?: American Influences on English Legal Education, c. 1870-1965" (2011) 18:1 \& 2 Intl J Leg Profession 7; Stephen C Hicks \& Kjell Å Modéer, eds, Globalization and the U.S. Law School: Comparative and Cultural Perspectives 1906-2006 (Lund: Juristförlaget i Lund, 2009); Matthew S Erie, "Legal Education Reform in China Through U.S.-Inspired Transplants" (2009) 59:1 J Leg Educ 60; Takahiro Saito, "The Tragedy of Japanese Legal Education: Japanese 'American' Law Schools" (2006) 24:1 Wis Intl LJ 197. On Harvard's general influence on Canadian legal education, see Willis, History of Dalhousie Law, supra note 6 at 14-15; Jerome E Bickenbach \& Clifford Ian Kyer, "The Harvardization of Caesar Wright" (1983) 33:2 UTLJ 162.

$9 \quad$ Kalman, supra note 6 at xi. 
environment. Secondly, as John Henry Schlegel points out, ideas are not self-executing. As Schlegel puts it, one should approach the history of ideas not as "the dance of reason," but instead as the "whole dance of life." "In other words, an intellectual history of law must also be a history of legal intellectuals in order to fully appreciate how ideas find expression in the actions and experiences of the figures holding them. This article, in attempting to understand how modern law schools came to be, approaches its subject as one of people and places and the migrations between them. In doing so, my purpose is neither to celebrate nor venerate, but rather to uncover and elucidate the weave of personality and praxis, ideologies and circumstance, roads travelled and abandoned in a case study of the making of modern university-based legal education.

This article unfolds in three parts. The first charts the life of Wilbur Bowker, and the circuitous and unorthodox route that brought his academic career to the University of Alberta, Faculty of Law, and then to graduate school at the University for Minnesota Law School. Bowker's story offers, in many ways, something of a microcosm for the history of university-based Canadian legal education in the twentieth century: modest beginnings, followed by the dramatic influence of the Second World War, and finally the emergence of a new professional identity and confidence in the postwar decades to follow. Following Bowker to Minnesota, the second part provides a history of Everett Fraser's attempt to reorient elite American legal education towards public service. Fraser's "Minnesota Plan," like other innovations in legal education, was the product of a cluster of ideas and administrative leadership, but also of time, place, and circumstance. It was reactionary as well as constructive, conservative and bold. And like so much of the law itself, it took form in grand rhetoric and ambition, but lived a more modest existence in the actual classrooms, hallways, and libraries of the law school. Now largely forgotten, it deserves a place of recognition in an overlooked moment of experimentation and change in North American legal education. The article concludes with Bowker taking up the deanship at the University of Alberta and charts the impact of Minnesotan and American legal education more broadly on Canadian postwar legal education. Throughout, the article tells a story of how the personal experience, attitudes, and talents of law professors enmeshed themselves in the practices, orientations, and philosophies of legal education. It reveals how networks of individuals - solidified in personal interactions, correspondence, and published writings transmitted and spread ideas between institutional settings and across borders. Finally, it is an excavation of a neglected, but crucial, period in the history of North American legal education when a bundle of ideas about the state, progress, and legal engineering expanded the curriculum and added a new public-minded aspiration to legal education. That model of legal education - its blended curriculum of private and public law, underlying assumptions about the profession, and teaching techniques and practices - dominated the field for much of the next half-century, and arguably still does. 


\section{Wilbur Bowker: The Accidental ACADEMic}

Wilbur Fee Bowker was born on 18 February 1910 in the small farm supply town of Ponoka, Alberta, some 100 kilometers south of Edmonton. ${ }^{11}$ In 1906, Bowker's parents, George and Ida, had left Quebec keen to find better fortunes in the West, desires their son later attributed to an adventurous "itchy foot." 12 Assisted by family connections - Ida's sister and brother-in-law, the town's Presbyterian minister, had already settled in Ponoka entrepreneurial George quickly found work as a clerk in the town's general store before accumulating enough capital to establish a funeral business. Two sons arrived in quick succession, Elwyn in 1908 and Wilbur not quite two years later. Briefly relocating to Regina, Saskatchewan to pursue a business opportunity that did not prove lucrative, the Bowker family returned to Ponoka in 1917 and established a successful lumber business. Upstanding members of the Presbyterian and then the United Church, politically conservative, and industrious, the Bowker family enjoyed modest prosperity, even during the worst years of the Depression.

"My father was always concerned that we boys not be idle," Bowker recalled of his boyhood. "He didn't want us playing pool or hanging around street corners." Instead, Wilbur spent his Saturdays "heaving planks around" the lumber yard and delivering the Edmonton Journal. ${ }^{13}$ But George and Ida Bowker also possessed a spirit of worldliness and adventure alongside their disciplined work ethic. They were determined to broaden their sons' horizons beyond the comfortable life of a small prairie town. Private tutoring ensured that their sons learned French, and most summers included an ambitious family trip, often driving across the country to visit relatives in the east, or exploring the United States: California one year, New York another. ${ }^{14}$ Academic success was equally expected. "I never had any choice about going to university," Bowker remarked, "it was just ordered." 15 And so in the fall of 1926, having completed grade 11 in Ponoka's six-room schoolhouse, and given that there were not

11 The 1911 census records Ponoka's population at 642, mostly of British heritage (Statistics Canada, The Canada Year Book, 1916-17 (Ottawa: Statistics Canada, 1917) at 104). By 1921, the population had grown to 1,594 (Statistics Canada, The Canada Year Book, 1925 (Ottawa: Statistics Canada, 1925) at 126) and, although still predominantly British in character, emerging numbers of immigrants of Japanese, Italian, and Ukrainian origin suggest the changing face of small-town Albertan life. Biographical and family details are taken from Marjorie Bowker, "Through the Years with Wilbur Bowker" (1987) [unpublished, archived at University of Alberta, Faculty of Law] [M Bowker, "Through the Years"]; Interview of Wilbur Bowker by Christine JN Kates (June 1987-April 1988), Toronto, Archives of Ontario (C 81-1-0-61) [Bowker Interview]; DT Anderson, "Wilbur Fee Bowker: In Appreciation" (1976) 14:2 Alta L Rev 199; W Wesley Pue, "The Making of Canadian Legal Scholarship: A Retrospective on A Consolidation of Fifty Years of Legal Writings, 1938-1988, by Wilbur F. Bowker" Book Review of A Consolidation of Fifty Years of Legal Writings, 1938-1988, by Wilbur F. Bowker by Marjorie M Bowker, (1993) 22:1 Man LJ 176. Unfortunately, Bowker left no personal papers beyond the edited memorial books compiled by his family, and most of the records of the Faculty of Law from the period of his deanship were destroyed in a fit of short-sightedness when the faculty moved to a new building in 1972 .

12 Originally from a farming hamlet in Southwestern Ontario, Ida had been sent as a young girl to Granby, Quebec in the Eastern Townships to live with her brother and finish school. There she met George. They married in 1905, a year before they moved to Ponoka. They came west aboard a "Colonist Car,"Wilbur Bowker explained, "primitive railway cars, [with] a stove at the end of the coach where you could make your meals" (Bowker Interview, ibid at 4).

Ibid at $11-12$.

Ibid at 21; M Bowker, "Through the Years," supra note 11 at 9. Bowker was especially pleased to have seen a double-header at Yankee Stadium, probably on 4 July vs. the Washington Senators. The Yankees won both games handily. It was a good year to see the Yankees. With Babe Ruth leading the way with his record-breaking 60 home runs, the Yankees won the pennant and the World Series. The team is widely regarded as among the best in baseball history. Bowker's love of baseball would endure. Bowker Interview, ibid at 21. 
enough students to conduct a twelfth grade, Wilbur moved to Edmonton to enroll in the sixyear combined Arts-Law degree at the University of Alberta. ${ }^{16}$ He would spend most of the rest of his life there.

In 1926 the University of Alberta, its handful of buildings situated along the wooded banks of the North Saskatchewan River, approached its twentieth anniversary, still run by its indomitable founding president, Henry Marshall Tory. The early years of expansion now entered a period of belt-tightening in keeping with the declining economic fortunes of the province. But bonhomie and varsity spirit still prevailed among a student body largely drawn from families much like Wilbur's own: "the small urban middle class in the province."17 Wilbur moved into a University residence on campus - a room he would occupy for the next five years - and began his program in Arts, quickly immersing himself in student life and his studies. "Work honestly, play heartily, and you will be a credit to our institution," the student paper, The Gateway, counselled - advice Bowker seems to have taken to heart. ${ }^{18}$ Indeed, it was at The Gateway that Bowker poured many of his hours, working his way from writer to managing editor and finally to co-editor-in-chief. Academically, his undergraduate program in Arts included courses in French, Philosophy, Economics, Political Science, and History. ${ }^{19}$ Looking back, he recalled with particular fondness the Canadian constitutional history classes of A.L. Burt, then one of the leading figures in the archival-based "renaissance" of Canadian history. ${ }^{20}$ In his charismatic and forceful lectures, Burt impressed upon his students the importance of knowing Canada's historical past - especially the role of Quebec - in understanding Canada's twentieth century prospects and possibilities. ${ }^{21}$ Known for emphasizing current events, Burt had plenty of constitutional material to weave into lectures, the King-Byng Affair of 1926 chief among them. ${ }^{22}$ Already keenly interested in Canadian history, government, and law, Bowker carried the imprint of Burt's passion for

A year earlier, the Benchers of the Law Society of Alberta had raised the standards of admission by decreeing that entrants to the Faculty of Law must have either a completed university degree or "evidence of satisfactory completion of two full years of college work in the Arts course as an undergraduate student in any college or university approved by the Education Committee." "Report of Committee on Legal Education" in Minutes of Proceedings of the Tenth Annual Meeting of the Canadian Bar Association (Toronto: Carswell, 1926) 223 at 224.

17 Women comprised of more than 30 percent of the student population during Wilbur's years as a student. Rod Macleod, All True Things: A History of the University of Alberta, 1908-2008 (Edmonton: University of Alberta Press, 2008) at 82-83.

18 "The Gateway Greets You," The Gateway (7 October 1926) 1. but not outstanding student. He received Second Class standing in his classes in French, History, and Political Economy in 1927 ("Final Examination Results: Faculty of Arts and Sciences," The Gateway (13 May 1927) 4); Latin in 1928 ("Final Examination Results: Faculty of Arts and Sciences," The Gateway (14 May 1928) 4); History, Philosophy, and Political Economy in 1929 ("Final Examination Results: Faculty of Arts and Sciences," The Gateway (14 May 1929) 4).

20 Lewis H Thomas, The Renaissance of Canadian History: A Biography of A.L. Burt (Toronto: University of Toronto Press, 1975) at 48.

21 Thomas, ibid at 74-75. Burt's major work, The Old Province of Quebec, first appeared in 1933. As George Stanley described Burt's lectures, "Here, at last, was the blood and life of Canada; here was my country, courageous, brash, sincere, controversial, at times even abrasive, cocking a snoot at the aggressive Americans." George FG Stanley, "The Making of a Historian: An Autobiographical Essay" in RC Macleod, ed, Swords and Ploughshares: War and Agriculture in Western Canada (Edmonton: University of Alberta Press, 1993) 3 at 9.

22 In 1926, Governor General Lord Byng refused Prime Minister Mackenize King's request to dissolve the House of Commons and call an election. Instead Byng called upon the Conservative opposition leader, Arthur Meighen, to form a government.When Meighen's government toppled soon after, King was returned to office on an election platform that stressed the need for greater Canadian constitutional independence. The event was widely seen as a galvanizing moment in Canada's still emerging constitutional independence. See Eugene A Forsey, The Royal Power of Dissolution of Parliament in the British Commonwealth (Toronto: Oxford University Press, 1943). 
Canadian constitutional history into his own scholarly career. As it turned out, Bowker was in one of Professor Burt's final classes at the University of Alberta. In 1930 Burt departed for the History Department at the University of Minnesota, a subtle influence, perhaps, on choices Bowker would make 16 years later. In 1929, Bowker completed his program in Arts with a sense of satisfaction, and began with anticipation to take courses at the Faculty of Law.

Housed in several rooms in the impressive Faculty of Arts building, Bowker, and a dozen or so classmates, including two women, entered a law school staffed by two full-time faculty members: Dean John Weir and Professor Malcolm MacIntyre. The faculty was supplemented by a handful of "over town practitioners," lawyers working downtown across the river, and a few prominent judges. The Law Faculty dated to 1912 when the University created a Department of Law to provide various lectures and administer examinations leading to the awarding of an LL.B. for the Law Society of Alberta. ${ }^{23}$ From the outset classes followed the Harvard-inspired casebook teaching method (heavily weighted with English and American appellate decisions), but the fact that students could bypass the degree to enter the bar directly discouraged the growth and rigour of the program. Seeking improvements, in 1921 the Law Society ceded to the Faculty of Law the exclusive responsibility of determining and delivering the content of three years of full-time lectures and examinations leading to a law degree, now a necessity for admission to the bar. ${ }^{24}$ The University had difficulty securing a suitable dean; both Percy Corbett, then at Oxford, and Ivan Rand, then in private practice, turned the position down. ${ }^{25}$ Finally, in 1926 Tory promoted one of his inaugural faculty members, John A. Weir, to the deanship. Weir, a graduate of the University of Saskatchewan's College of Law and a Rhodes Scholar having studied Jurisprudence at Oxford, was only 27 when he arrived at the University of Alberta, and 33 when appointed dean. He was widely lauded for his brilliant mind, capacity in private law, and dedication to the Faculty of Law in its formative years. ${ }^{26}$ MacIntyre, originally from New Brunswick,

On the pre-University years of legal education in the West and the founding and first decade of the Faculty of Law, see Sibenik, supra note 6 at 439-40. See also Law \& Wood, supra note 5 at 4-5.

Sibenik notes that the negotiations between the profession and the University proceeded quickly and smoothly - in contrast to the more tortured deliberations that would last many decades in Ontario. The fact that the University's negotiating team included President Tory, Chief Justice Horace Harvey (chairman of the University's Board of Governors), and Justices Charles Stuart and ND Beck surely helped. As well, many benchers of the Law Society had university law degrees, four of them from Dalhousie (Sibenik, ibid at 456-57). Wes Pue also persuasively argues that "[ $[$ ] fluidity, lack of established institutions and smorgasboard of utopian visions liberated élites from convention" (Pue, "Common Law Legal Education," supra note 6 at 661).

25 Percy Corbett eventually returned to North America taking up the deanship at McGill, and, after that, professorships in international law at Yale and Princeton. Ivan Rand, of course, went on to serve on the Supreme Court of Canada and, after retirement, as dean of the Faculty of Law at the University of Western Ontario. It was Roscoe Pound who initially recommended Rand to the President of the University of Alberta, Henry Marshall Tory. Rand had recently spent seven years practicing law in Medicine Hat, Alberta, but a decline in the economic fortunes of the West and family pressures drove Rand home to New Brunswick in 1920. When Tory reached out to Rand to return to Alberta as dean of its law school in 1921, Rand declined. Letter from Roscoe Pound to Henry Marshall Tory (17 June 1921), Edmonton, University of Alberta Archives (\#68-69, Box 10, Folder 122); Telegram from Henry Marshall Tory to Ivan Rand [nd], Edmonton, University of Alberta Archives (\#68-69, Box 10, Folder 122); Telegram from Ivan Rand to Henry Marshall Tory (7 June 1921), Edmonton, University of Alberta Archives (\#68-69, Box 10, Folder 122). I thank Matthew Lewans for alerting me to the Tory-Rand correspondence.

26 "It is impossible for those who did not know him as a teacher," Anderson writes, "fully to understand, or explain, the remarkable dedication, respect and affection this man evoked from the students and the profession. We know that he was very young; that he carried a teaching burden that no one today could tolerate; that his scholarship was exact, and that no matter how great the range of courses he taught, he seemed master of each subject" (Anderson, supra note 11 at 202). See also MM MacIntyre, "John Alexander Weir, K.C., B.A., LL.B” (1943) 5:1 Alta L Q 1; Law \& Wood, supra note 5 at 10. 
joined the Faculty in 1930, after taking both his Bachelor's and Master's degrees in law at Harvard under the influence of Roscoe Pound. Between them, Dean Weir and Professor MacIntyre taught the majority of Bowker's courses.

The intimate law school classes Bowker and his classmates encountered relied overwhelmingly and self-consciously on Langdell's Harvard-inspired case method of teaching. ${ }^{27}$ With the absence of commercial casebooks, most courses relied on long lists of cases to be read and digested before class. Alberta based its course offerings on the Canadian Bar Association's recommended curriculum, itself modelled on the curriculum of Dalhousie Law School, which, in turn, had borrowed its program from Harvard. ${ }^{28}$ All courses were mandatory: alongside his ever-present classmates, Bowker took Contracts, Torts, Criminal Law, and Property in first year (1929-30); Bills and Notes, Constitutional Law, Jurisprudence, Legal History, Practice I, Property II, Sales, and Wills and Administration in second (1930-31); and Company and Municipal Law, Criminal Procedure, Domestic Relations, Evidence II, Equity II, Legal History II, Partnership and Agency, Practice II, and Private International Law in third year (1931-32). As one might expect given the amount of time spent together, both Weir and MacIntyre left lasting impressions. Bowker recalled the "roly-poly" Weir as a "master of the Socratic method" and "one of the greatest law teachers who ever came along," and MacIntyre with a certain bemused affection as "the most disorganized man you ever encountered." ${ }^{29}$ In the tribute he penned after MacIntyre's death several decades later, Bowker admitted that early on "some students might have been taken aback by his irreverence to black-letter law and his sociological approach. ${ }^{30}$ Especially compared to the authoritative confidence of Weir, students sometimes perceived MacIntyre's "uncertainties and doubts" as signals of incompetence. "As time passed, however," Bowker reminisced, "he [succeeded] in communicating his concern about the human importance of legal rules and his strong sense of injustice." ${ }^{31}$ Committed to the academic enterprise, MacIntyre founded the Faculty's first scholarly journal, The Alberta Law Quarterly in 1934. ${ }^{32}$ His academic stature grew all the larger with the publication of his classic (and still cited) article on negligence in the Harvard Law Review. ${ }^{33}$

$27 \quad$ "The law school is modeled after the Harvard practice, which is the greatest law school in the Englishspeaking world today. The case method of study, which is used there and is recognized to be the best known system for the study of law, is also in use at the Alberta school": "First Class in Law to Graduate," The Gateway (14 May 1924) 1.

28 See Committee on Legal Education, "Standard Curriculum" in Proceedings of the Fifth Annual Meeting of the Canadian Bar Association (Winnipeg: Bulman Bros, 1920) 250 at 250-51.

29 Bowker Interview, supra note 11 at 28. As another student recalled, "Dean Weir ... was never stiff or formal in manner with his students and enjoyed engaging with them on occasion in repartee in which it was fruitless to attempt to best him." David Sigler, "Remembrances of the Faculty of Law at the University of Alberta" 2020 Anniversary Celebration Program (September 1992) [unpublished, archived at University of Alberta Law Library] at 9.

30 WF Bowker, "Malcolm Murray MacIntyre: 1904-1964" (1964) 3:2 Alta L Rev 161 at 161 [W Bowker, "Malcolm Murray MacIntyre"].

Ibid.

As MacIntyre put it: “The Quarterly is my child and I run it even to the proof-reading. Frankly, I don't think much of it, but when it is superimposed on my teaching and moot-court work, I think it shows that I am giving the University of Alberta and the students enough to make me a not unwelcome addition to a law school faculty." MacIntyre to Read (10 January 1938), Halifax, Dalhousie University Archives (Read Papers).

33 Malcolm M MacIntyre, "The Rationale of Last Clear Chance" (1940) 53:8 Harv L Rev 1225; also published as Malcolm M MacIntyre, "The Rationale of Last Clear Chance" (1940) 18:9 Can Bar Rev 665. "The tone of the article," Bowker summarized "is pure MacIntyre: humorous, ironical and impatient” (W Bowker, "Malcolm Murray MacIntyre," supra note 30 at 161). 
In Weir and MacIntyre, Bowker received two variants of the period's dominant modes of law teaching: Weir, the British-trained confident purveyor of common law analysis; and MacIntyre, the American-trained academic taking the first tentative steps toward situating law in a broader social context. Outside of classes, the heart of the law school was undoubtedly the Law Library. As Bowker described, "[e]ach student had a chair and desk space - third year by the lighted front windows, second in the middle and first towards the west wall." ${ }^{34}$ There, amidst the modest collection of well-worn journals and law reports, law students formed a tight community typified by close relations with their professors and each other, while reinforcing the subtle and persistent social hierarchies of law school: third year students naturally got the best seats. ${ }^{35}$ Bowker - with his easy manner and capacity for friendships - cemented several lasting bonds during law school. As in his Arts courses, academically Bowker performed reasonably well, never at the top of his class but typically earning second class standing, and the odd third class result. ${ }^{36} \mathrm{He}$ also remained active in student life, including his editorial work at The Gateway and, by the closing years of law school, as a founding member and president of the University of Alberta chapter of the fraternity Delta Kappa Epsilon. In 1932 Bowker graduated rich in friendships, satiated with legal doctrine, and brimming with promise headlong into the bleak employment prospects of the Great Depression.

Securing a law degree in the 1930s was no guarantee of finding employment. ${ }^{37}$ "I spent the summer of 1932 looking for a place to article, and I knocked on doors from Calgary to Edmonton and points in-between," Bowker recalled. ${ }^{38}$ Finally, in September, George Steer, one of Bowker's former "over town" instructors, agreed to take him on. ${ }^{39}$ Born in 1886 in Hamilton, Ontario, Steer arrived in Edmonton in 1912 with a degree from Queen's University and, after three years of articles, was called to the bar in 1915. Over the course of the next several decades, taking an array of criminal, civil, and constitutional cases, Steer — "[a] tough ... very well built man, stern looking, no nonsense" — became one of Edmonton's leading litigators. "He was a hard worker," Bowker recalled "prompt and

36

2020 Anniversary Celebration Program, supra note 29 at 11.

On the acculturation aspects of Canadian legal education in this period, see Mélanie Brunet, "Good Government, Without Him, Is Well-Nigh Impossible': Training Future (Male) Lawyers for Politics in Ontario, Quebec, and Nova Scotia, 1920-1960" in Constance Backhouse \& W Wesley Pue, eds, The Promise and Perils of Law: Lawyers in Canadian History (Toronto: Irwin Law, 2009) 49.

Results are taken from the May 1930, 1931, and 1932 issues of The Gateway, see "Final Examination Results: Faculty of Law," The Gateway (14 May 1930) 2; "Final Examination Results: Faculty of Law," The Gateway (14 May 1931) 2; "Final Examination Results: Faculty of Law," The Gateway (12 May 1932) 4-5. As Bowker explained of the curriculum, "Our faculty had two full-time people, and to economize in teaching, in second and third years, most of the courses were given every other year." Bowker Interview, supra note 11 at 27-28. Among the "overtown" instructors who taught Bowker were LY Cairns, Alan Harvey, William Dixon-Craig, HA Dyde, and George Steer.

Bowker's situation was replicated across the Prairies. Although he had graduated as Manitoba's gold medalist in Law in 1938, Brian Dickson, later Chief Justice of the Supreme Court of Canada, could not find articles: his first job was at the Great West Life Assurance Company. Robert J Sharpe \& Kent Roach, Brian Dickson: A Judge's Journey (Toronto: Osgoode Society for Canadian Legal History, 2003) at 46.

Bowker Interview, supra note 11 at 35.

Bowker repaid the favour 50 years later with a 55-page tribute in the Alberta Law Review: WF Bowker, "Fifty-Five Years at the Alberta Bar: George Hobson Steer, Q.C." (1982) 20:2 Alta L Rev 242 [W Bowker, “George Hobson Steer"].

Bowker Interview, supra note 11 at 37 . Conjuring the man in his tribute was not easy, Bowker admitted. " $[\mathrm{H}] \mathrm{ad}$ he been loquacious or given to moralizing or reminiscing it would have been easier to paint a picture," he noted. "Peculiarly a private man, he kept personal matters and his thoughts and beliefs to himself," W Bowker, "George Hobson Steer," ibid at 294. Steer eventually led the prominent firm Milner \& Steer, which lives on in a manner of speaking. In 2012 Fraser Milner Casgrain LLP merged with the large international firm, Dentons. 
thorough, and single-minded in his attention to clients' affairs - and he expected others to be the same." ${ }^{41}$ Bowker earned $\$ 25$ per month and spent the majority of his articles "running around" serving documents, listing properties for sale, searching land titles, drafting legal memos, and accompanying Steer to trials. ${ }^{42}$ Called to the bar on 12 December 1933, Bowker stayed with Steer's firm and moved with him when Steer formed a successful new partnership in 1934 with H.R. Milner, another of Edmonton's leading lawyers. As it happened, Bowker's talented, taciturn, and demanding mentor would change the course of his life.

The most profound impact on Bowker's life was provided not by Steer himself, but one of the law students he hired, Marjorie Montgomery. Born on Prince Edward Island (and a distant relation to the Island's most famous Montgomery, Lucy Maud), Marjorie's family moved to Wetaskiwin, Alberta, a small town just south of Edmonton when she was four. Having also graduated from the combined Arts-Law degree at the University of Alberta, Steer hired Montgomery as a summer student in 1937, and she began her articles with Steer after graduating near the top of her class in 1939. Engaged by the summer of 1938, Wilbur and Marjorie married in the autumn of 1940 at the United Church in Wetaskiwin. ${ }^{43}$ In the years preceding the wedding, Bowker had successfully worked his way from student, to associate, to named partner in the firm. ${ }^{44}$ In that time he had become fast friends with another of the firm's young lawyers, Ronald Martland, a future justice of the Supreme Court of Canada. Although Martland remembered the 1930s as lean - "most Alberta lawyers had to make their living by swearing each other's affidavits under the Debt Adjustment Act" their firm, eventually Milner Steer, began to attract the leading litigation work in Edmonton and prospered. For his part, Bowker never quite developed into a leading counsel or firm rainmaker, in his handful of reported cases he served as second counsel to Steer, but his academic bent and research ability, precise memory, and diligent work ethic provided valuable contributions to the firm nonetheless. ${ }^{46}$ As the firm succeeded, and just as Bowker's position within it solidified, the world fell into crisis.

At 29, engaged to be married, and a busy professional, Bowker was an unlikely recruit when Canada declared war on Germany in September 1939. Nevertheless a strong sense of service pulled him to contribute to the war effort. Almost immediately, Bowker joined the Army Reserve in Edmonton, training in firearms use two nights a week at the local Armories, and attending summer training camps in 1940 and $1941 .^{47}$ By January 1942, he had earned

Among the cases passing through the firm that year was the famous student hazing case, Powlett $v$ University of Alberta, [1933] 3 WWR 322 (Alta SC), aff'd in part [1934] 2 WWR 209 (Alta SC (AD)). After suffering a mental breakdown following a hazing at the University of Alberta, Powlett claimed for damages against the University. Powlett won $\$ 50,000$ at trial, reduced to $\$ 15,000$ on appeal. The matter settled pending an appeal to the Privy Council.

43 Marjorie Bowker to John Martland (20 April 1999) in Marjorie Bowker, ed, Memorial Book Honouring Wilbur F. Bowker [unpublished, archived at University of Alberta Faculty of Law]; M Bowker, "Through the Years," supra note 11 at 23-30.

$44 \quad$ In 1937 the firm became Milner, Steer, Poirer, Martland \& Bowker.

45 Martland Interview (19 May 1982), Edmonton, Provincial Archives of Alberta (PR 87.330 vol. 14, Calgary Bar Association Oral History Project).

46 Putting it at its highest, Anderson writes that "Bowker had much to do with the development of mortgage proceedings in [Alberta] ... and did much of the staff work in preparing the appeal to the Judicial Committee on the famous case, still cited in the torts textbooks, the "Corona Hotel Case", (Anderson, supra note 11 at 203).

47 
a Commission at the rank of Second Lieutenant with the 3rd Active Battalion of the Edmonton Fusiliers, a position he promptly resigned later that year so he could enlist as a private in the infantry. ${ }^{48}$ Bowker wanted to go to war. Over-age, and taking a leave of absence from his law firm (with Marjorie assuming responsibility for his files and clients), Bowker reported for duty at Sarcee Camp just outside of Calgary. Despite his desire to see action, Bowker spent the war in Canada. Eventually rising to the rank of Captain, Bowker continued his training and service in Calgary, Nanaimo, Prince George, and Kingston before being transferred to National Defence Headquarters in Ottawa, serving on a staff of mostly fellow lawyers in the Adjutant General's Branch, Administration and Discipline. ${ }^{49}$ When the war ended, Bowker began to contemplate a return to Edmonton, civilian life, and the resumption of his law practice. But events at the University of Alberta, Faculty of Law of which he may have only been dimly aware, were conspiring to alter his postwar plans.

The University of Alberta, Faculty of Law weathered the years of war with diminishing resources and falling enrollment, but just barely. In the decade after Bowker's student days, the Faculty of Law had grown modestly, but steadily, in student numbers. "The unsettled external situation has not, as yet, had any very marked effect on academic work," Dean Weir optimistically reported in $1940 .{ }^{51}$ Weir and MacIntyre continued to teach the bulk of the curriculum, the Faculty continued its close and co-operatively productive relationship with the Law Society, and most students found articles. But Weir's sanguinity was not to last. As the war dragged on, student numbers fell precipitously. Twenty-four students entered first year law in the fall of 1939 for a total student enrollment of just over 60, but by 1944 the total number of students had fallen to eight, with the prospect of no students entering first year. A further setback to the Faculty occurred in June 1942, when Dean Weir, not yet 50, died suddenly of a heart attack. The University appointed MacIntyre dean, but it quickly became apparent that administrative work did not suit him. Although he took important strides in modernizing the class offerings of a curriculum that had been static for more than a decade - he sought to add courses in administrative law and taxation ${ }^{52}$ — the strain of leadership, and the Faculty's precarious financial state, became increasingly apparent in MacIntyre's frayed correspondence with the university president. ${ }^{53}$ In the summer of 1944 ,

48 Explaining his choice, Bowker remarked that "he had not learned law on a part-time basis; and he did not expect to become a soldier by part-time training" (M Bowker, "Through the Years," ibid at 34).

Ibid at 34-41. So desperate was Bowker's desire to see active service that he requested a transfer back to the Infantry in the spring of 1945. Returned to training in Calgary and then Vernon, Bowker's unit was preparing for overseas service when he fell ill with a respiratory infection placing him in the Military Hospital. Victory in Europe Day, 8 May 1945, ended any of Bowker's remaining hopes for seeing the front and he returned to Ottawa.

50 At the close of the 1938-39 academic year, Dean Weir reported 61 total LL.B. students, continuing close and co-operative relations with the Law Society, and the reasonably successful placement rate of its graduates: Report of the Board of Governors and the President of the University of Alberta (1938-1939) [unpublished, archived at University of Alberta Faculty of Law] at 27.

51 Report of the Board of Governors and the President of the University of Alberta (1939-1940) [unpublished, archived at University of Alberta Faculty of Law] at 29.

$52 \quad$ "The Law School should expand and should offer courses calculated to enable its graduates to fit into a wider variety of activity than the Law Schools of the past have envisaged." Preliminary Report of Malcolm MacIntyre (27 July 1942), Edmonton, University of Alberta Archives (68-1 3/4/5/9/1, "General Correspondence," Robert Newton Papers).

53 Falling enrollment and revenues prevented hiring a replacement for Weir and finding part-time instructors to fill the gaps also proved difficult. "Due to the war," MacIntyre complained "such men are not available" (ibid). In his letter to Newton, 15 May 1943, MacIntyre apologized for missing convocation and returning to New Brunswick but, citing the extraction of all of his teeth, and the stressful demands of attempting to complete Dean Weir's unfinished manuscript, he stressed that he was "not taking a holiday." After listing a number of his work obligations, the tone became more desperate the following spring: "But I will not worry you with a list of my woes because it would be long and we 
with the law school largely empty and in disarray, Dean MacIntyre, the only full-time faculty member, requested a leave of absence in order to return to his family law practice in Sackville, New Brunswick. ${ }^{54}$ In MacIntyre's proposal, first year law would be " $[\mathrm{t}]$ emporarily discontinued" ("[i]f first year students appear ... they be permitted to take the regular second year courses"), Steer would take over all administrative responsibilities and supervise the part-time instructors, and MacIntyre would teach Jurisprudence by correspondence. "Law is all more or less the same," he justified, "and prerequisites in the usual sense do not exist. Any first year ... students who do this can later take their first year courses when the first year is restored. This is not the most desirable way to run a law school, but then neither is it desirable to conduct classes for one, two, or possibly three students." "As with most things today," he bleakly concluded, "it is not a choice between good and evil but between two evils." ${ }^{55}$ MacIntyre never returned. ${ }^{56}$

The search for a dean to replace MacIntyre began in earnest in the summer of 1945 . President Newton immediately targeted George Curtis - like Weir, a graduate of the University of Saskatchewan and a Rhodes Scholar, then teaching at Dalhousie Law School. As Newton frankly conceded in his recruitment letter, "Dean MacIntyre has just resigned because for an indefinite period he has no prospects of returning. We are thus in the position of having to start from scratch in building up our Law School again." 57 Despite initial interest, Curtis opted to become the University of British Columbia's (UBC) founding law dean instead. ${ }^{58}$ The search continued with Newton pressing his contacts across the country

all have them. However, I feel that since I cannot, in the number of hours that there are in each week do adequately more than a fraction of my work, I should spend my time on what concerns the Law School most and on what I alone can do.... The general thesis of this note is that everything I do must be done at the sacrifice of something else which I should do and that I hope you will forgive me for frequent unavoidable absence from meetings." MacIntyre to Newton (30 March 1944), Edmonton, University of Alberta Archives (68-1 3/4/4/9/1, "General Correspondence," Robert Newton Papers).

54 MacIntyre to Newton (1 August 1944), Edmonton, University of Alberta Archives (68-1 3/4/4/9/1, "General Correspondence," Robert Newton Papers). "Everybody seems to agree that I would gain considerably from experimenting with practice," MacIntyre explained. By the end of his letter, however, a different picture emerges. MacIntyre needed a break: "I will be able to look after my family, find out what is involved in the practice of law and whether I am any good at it, and have a complete change which after fourteen years of overwork, I need." In fact, MacIntyre had been attempting to leave for some time. As early as 1938, MacIntyre was on the hunt for "a more suitable teaching position" elsewhere, including the University of Minnesota Law School. MacIntyre to Read (10 January 1938), Halifax, Dalhousie University Archives (Read Papers).

MacIntyre to Newton (1 August 1944), Edmonton, University of Alberta Archives (68-1 3/4/4/9/1, "General Correspondence," Robert Newton Papers).

Although he did return to teaching law, joining the UBC Faculty of Law in 1948, where he remained until his death in 1964.

57 Newton to Curtis (11 July 1945), Edmonton, University of Alberta Archives (68-1 3/4/4/9/1, "General Correspondence," Robert Newton Papers).

58 "I have a rather guilty feeling about George Curtis," UBC's President, Norman MacKenzie wrote apologetically to Newton, "I am sorry if I have caused you any inconvenience." MacKenzie to Newton (30 August 1945), Edmonton, University of Alberta Archives (68-1 3/4/4/9/1, "General Correspondence," Robert Newton Papers). “Actually you stole him from under our very noses," Newton replied "as we had completed all the preliminary negotiations by mail and he had come out to meet a special committee of the Board.... In spite of the fact that we have still not a single full-time teacher lined up for our term which opens on September 24, I am quite ready to forgive you and to congratulate you upon getting an excellent man." Newton to MacKenzie (4 September 1945), Edmonton University of Alberta Archives (68-1 3/4/4/9/1, "General Correspondence," Robert Newton Papers). It probably did not help to ease the sting that Curtis had initially agreed to visit UBC as an extension of his trip to Edmonton to meet Newton about the deanship. In his own recalling, Curtis suggests he was never as close to a deal as Newton implied. "So we had many discussions for two days," he remembered, "and I went back to my hotel. I think I can say now that I wasn't too happy with the set-up at the University.... I wasn't too impressed with ... the arrangements that they had there ... I couldn't get any clear idea of what was planned.... In any event, I was pretty negative in my mind. I hadn't made up my mind but it wasn't too favourable" (reprinted in Pue, Law School, supra note 6 at 142). 
to find a capable administrator. He had not given up entirely on the idea of finding an individual with seasoned experience, but he also recognized that, in the circumstances, he may need to "look for some young man with such outstanding promise as to justify promoting him immediately to bigger things. ${ }^{~} 59$ Newton set up meetings with a handful of potential candidates serving in senior wartime posts in Ottawa in early September. ${ }^{60}$ All were found uninterested, unavailable, or wanting, with the exception of Commander Horace Read, then on leave from the University of Minnesota, who expressed interest in being considered the following year. The trip did offer one immediate consolation. "While in Ottawa,"Newton reported to McGill's dean, "I succeeded in getting one of our own early graduates in Law released from the Army, and he will help us out this year." Newton had hired Wilbur Bowker.

Just before Newton had left on his trip east to look for a dean, Steer had suggested that he should meet with Bowker to see if he would join the Faculty for a year as a stopgap measure. Justice Harold H. Parlee, Chair of the Board of Governors, father of Bowker's classmate and friend Bill Parlee, and the éminence grise of the Faculty, approved the arrangement. Bowker, conveying a sense in which all of this lay beyond his control, remembered it this way:

[I]n early September the President of our University wired me to have lunch with him at the Chateau [Laurier] on Sunday, September 9, and so I did.... [Newton, Steer, and Parlee] had a talk and this deal was worked out. They were worried about having nobody full-time for these laddies coming out with their uniforms from all the three services. So the deal was this, that Mr. Steer would lend the university my services for the year, if I was willing, and if Dr. Newton ... could get me out of the Army.... I had my talk with Dr. Newton and went back to our little suite ... and talked it over with my wife, and we said, "okay.",61

Wilbur proceeded to Calgary to receive his official discharge on 26 September. He returned to Edmonton the following day to begin work as a law professor. ${ }^{62}$ Classes had already begun. The library was in shambles: the few remaining books were mostly torn and disorganized, and single forlorn copies of the SCRs and DLRs had not been bound since Weir died. ${ }^{63}$ But to everyone's surprise, 25 students appeared seeking to enroll (or re-enroll after returning from military service) in first year law. "[H]ere were all these boys in uniform," Bowker recalled, "sailors, sergeants, squadron leaders ... majors, all ranks ... they were nearly all veterans." ${ }^{64}$ Supressing panic, Bowker wrote to MacIntyre seeking outlines for the half-dozen courses he had agreed to teach: torts, real property, personal property, wills, jurisprudence, and recent cases. "I haven't got any outlines of courses," MacIntyre unhelpfully replied, "Marjorie will have better notes than I have." ${ }^{65}$ And so Bowker began

Newton to JB Collip (11 August 1945), Edmonton, University of Alberta Archives (68-1 3/4/4/9/1, "General Correspondence," Robert Newton Papers).

60 Among the pursued candidates Newton made inquiries after and set up meetings with Major CK Tallin, George VV Nicholls, and George Challiers in private practice in Ottawa.

${ }_{61}$ Bowker Interview, supra note 11 at 70-71. The "we" in the final sentence is significant. Marjorie Bowker would come to play a critical role in Bowker's deanship.

62 M Bowker, "Through the Years," supra note 11 at 50. Having sublet their apartment until December, the Bowkers spent the first six weeks as tenants in an Edmonton rooming house sharing a bathroom with the other tenants.

63 Bowker recalled the library containing "one set of the English Law Reports ... one set of the SCRs ... one set of the Western Weeklys, and the DLRS, and ... a handful of textbooks": Bowker Interview, supra note 11 at 165 .

${ }^{64}$ Ibid at 126, 168. "I admitted students personally, because I was the only one around. We were very sympathetic to veterans."

$65 \quad$ Ibid at 72. 
"completely from scratch." "I was chucked into teaching fourteen hours a week," Bowker marvelled in retrospect, "and I had never taught law before at all. And this was quite an experience. It was quite an adventure." 66

Although Bowker harboured a gentle resentment that MacIntyre had "let the law school down," his former professor had at least been right in this: Marjorie's notes did come in handy. ${ }^{67}$ With Marjorie helping to prepare his lectures, and crafting and organizing the moot problems, and with Bowker staying one lecture ahead of his students with nocturnal visits to the (better stocked) library of his former law firm, they survived the year. Suitably impressed (and with few other options), Newton offered Bowker a permanent position on the Faculty, but hinted obliquely that it would be preferable if Bowker somehow secured a graduate degree. ${ }^{68}$ Bowker felt torn. While the challenges of the year had been invigorating and certainly satisfying, he had always imagined himself returning to his career at his law firm. Certainly life back at Milner Steer offered far greater financial rewards. But service and duty mattered to Bowker and there was no doubt that the Faculty of Law needed him. Surely too he weighed his potential for impact in either career: at the law firm he was second counsel and had been nearly five years out of practice, at the law school he was basically in charge of the legal education of an entire province's lawyers. He may also have admitted to himself that his talents and temperament seemed better suited to the classroom than the courtroom. Finally, Bowker had not been to war as he had hoped, but there may have been something in the camaraderie among those student veterans, as well as the institutional routine and order, that offered a familiar and exciting reminder of life during the war. "If I hadn't been in the Army I don't think I could have handled it," Bowker remarked of that first year. ${ }^{69}$ And when he decided to stay, it was the faces of those veteran students - and the sentiments of the barracks - that seemed to tip the balance. "[I]t was a great year," he claimed wistfully; "I don't know how I kept a jump ahead of these boys, but those boys are among my best friends."

Having secured Bowker as the Faculty's professor for the short term, the President's search for a dean and other faculty members continued in earnest. Letters scattered across the country — including Steer's "cry of distress" to Caesar Wright in the fall of 1945 — in a desperate search for someone to take the reins. Most entreaties led nowhere, and a few more promising leads ended in failure. Negotiations with Vincent MacDonald of Dalhousie broke down when the University balked at his demands for a well-financed law library. ${ }^{71}$ Efforts to entice Horace Read to take the deanship resumed, and he visited the Faculty in February 1946. ${ }^{72}$ Read was an intriguing candidate. Born in Port Elgin, New Brunswick in

Ibid

"I have kept my mouth shut about it pretty well for 40 years," Bowker admitted, "if you knew MacIntyre you couldn't stay cross at him. But that was the form of irresponsibility he had. He had no sense of having let the law school down." "[I]f it hadn't been for my wife, I don't know how I would have done it." Ibid at 128 .

Ibid at 193 .

Ibid at 72 .

Ibid.

Ibid at 186. In 1950 the Faculty's library holdings stood at 7,000, one of the smallest in the country. The University of Toronto, by contrast, boasted almost four times that number: Maxwell Cohen, "The Condition of Legal Education in Canada" (1950) 28:3 Can Bar Rev 267 at 302.

72 "I have a keen interest in your proposal that I become Dean of your Law School," Read wrote to Newton, no doubt raising his hopes that his search for a dean might be coming to an end. Read to Newton (11 February 1946), Edmonton, University of Alberta Archives (68-1 3/4/4/9/1, "General Correspondence," Robert Newton Papers). 
1898 and educated at Acadia University, Read took his LL.B. at Dalhousie, and his LL.M., and later, doctorate, at Harvard. He had taught at Dalhousie Law School since 1925 before taking a leave to pursue his S.J.D. under Professor Joseph Henry Beale. ${ }^{73}$ Pound too emerged as a mentor and friend, and he encouraged Read to take up employment at an American Law School. Read did so in 1934, joining the University of Minnesota as an expert in legislation, largely on the strength of a glowing reference from Pound. ${ }^{74}$ Read spent much of the war in Ottawa serving as a Commander in the Royal Canadian Navy Volunteer Reserve acting as Chair of the Naval Orders Committee drafting wartime legislation. ${ }^{75}$ The visit to the University of Alberta campus and meetings with Bowker, Steer, and President Newton, however, failed to convince Read, and he too turned the University down.

Read's winter recruitment visit to Edmonton may not have produced a dean, but it did plant a seed and germinate a plan that eventually led to one. Before departing, Read offered the President and Bowker some sage advice. With Bowker staying on, why not send him to obtain his graduate degree at Minnesota? "Since my return to Minneapolis I have been investigating ... the possibilities of summer graduate work leading to a degree in this country," Read wrote to Bowker. "After investigating the field I have concluded that the best choice for you would be Minnesota." "76 The University of Minnesota Law School had a ready solution to the difficult problem of how Bowker could simultaneously run one law school and attend another as a graduate student. Like Alberta, Minnesota had seen its student enrollment fall sharply and then expand dramatically at the end of the war. Initially to deal with the uncertain comings and goings of its enlisted students, Minnesota had moved to a year-round four-semester, or "quarters system", whereby law students could initiate or resume their studies at any point during the year, including during a newly instituted summer term running June to August. That Read offered Bowker "a room at our house for a relatively small rental" seemed to seal the deal. ${ }^{77}$ Anxiously, Bowker sent Read his university transcripts and reported that he had followed up on Read's suggested reading. ${ }^{78}$ A month later, Read replied that Bowker had been accepted. ${ }^{79}$ In June 1946, with classes over, his marking done, and his university job secure, Associate Professor Bowker boarded the train, his luggage heavy with books and expectations, and headed east to graduate school at the University of Minnesota Law School.

Read published his dissertation as Horace Emerson Read, Recognition and Enforcement of Foreign Judgments in the Common Law Units of the British Commonwealth (Cambridge, Mass: Harvard University Press, 1938) [Read, Recognition and Enforcement].

$74 \quad$ Fraser to Read (31 May 1934), Halifax, Dalhousie University Archives (Read Papers).

75 On Read, see Read to Newton (18 August 1945), Edmonton, University of Alberta Archives (68-1 3/4/4/9/1, "General Correspondence," Robert Newton Papers), with attached curriculum vitae; "A Distinguished Life of Service," Halifax Chronicle Herald (1 March 1975) 6; Philip Girard, "Who's Afraid of Canadian Legal History" (2007) 57:4 UTLJ 727 at 736.

Read to Bowker (8 March 1946), Halifax, Dalhousie University Archives (MS 2-322, Read Papers). Ibid.

"I have been reading all I can on Jurisprudence," Bowker enthused, "particularly Roscoe Pound — and articles in the Harvard Law Review - and I have several recent books on Administrative Law which I hope to read soon. Incidentally, I have consulted Prosser continually since you were here [almost certainly Prosser's Handbook of the Law of Torts, Hornbook Series (St Paul, Minn: West, 1941)]. I have almost finished the book "Studying Law" edited by Arthur Vanderbilt." Bowker to Read (18 April 1946), Halifax, Dalhousie University Archives (Read Papers).

79 Read to Bowker (8 May 1946), Halifax, Dalhousie University Archives (Read Papers). 


\section{The Minnesota Plan: "A More Perfect Justice”}

In the winter of 1930, Everett Fraser, Dean of the University of Minnesota Law School, penned a vigorous letter of despair and hope to his university's president. Lawyers trained to serve only the narrow interests of their clients and "to follow the beaten path" were failing society, Fraser lamented. ${ }^{80}$ Having recently sat on the Minnesota Crime Commission, Fraser noted that lawyers instinctively opposed legal reform. ${ }^{81}$ The problem, at least in part, was law school: its narrow curriculum, unmotivated students, and vocational self-conception. A new four-year degree, Fraser argued, could offer change by expanding its course offerings to develop an appreciation of legal culture, law and society, and the administration of justice. Enlivened by this "broader vision," law students would "see law as a phase of human relations varying in time and place," legal history, criminology, and comparative law would hone "a flexibility of mind," and legal philosophy would provide "a sense of direction in his professional activities." ${ }^{\prime 2}$ In the years that followed, Fraser gathered an exceptional faculty to implement his vision: Stefan Riesenfeld to teach social legislation, Maynard Pirsig to teach judicial administration, and Horace Read to teach legislation, among others. In its focus and methodologies, but not without controversy and critics, the Minnesota Plan offered a new orientation for elite state school American legal education. Wilbur Bowker arrived in Minneapolis at the height of the Minnesota Plan's success and influence, but also within sight of its demise.

Established in 1888, the University of Minnesota Law School had, by the 1940s, risen from modest origins to become one of the leading law schools of the United States. ${ }^{83}$ There is much that would have been familiar to Bowker when he arrived at the steps of the Law School's imposing brick façade on Minnesota's large and leafy campus in the early summer of 1946. In many respects, university-based American legal education (putting aside the numerous night schools which continued to educate a large share of American lawyers) shared the basic structure of Canada's university-based law schools. Law school on both sides of the border consisted of a mandatory curriculum focused on private law subjects. A handful of full-time professors taught a large number of courses using casebooks of appellate cases in lectures mixing exposition and Socratic method. The model owed much to Harvard's basic curriculum and Langdell's case method, which, in the early twentieth century, had spread like a river spilling its banks as legal education professionalized and Harvard graduates carried its theories and methods into the reaches of many of North America's law schools. ${ }^{84}$

Fraser to Coffman (3 February 1930) Minneapolis, University of Minnesota Archives (Law School Papers, 413, Box 10).

As he later put it, "the legal profession is all brakes and no engine" (Everett Fraser, "An Integrated Course of Training for Lawyers" (1937) 8:8 American L School Rev 714 at 714 [Fraser, "Integrated Course"]).

Fraser to Coffman (3 February 1930), Minneapolis, University of Minnesota Archives (Law School Papers, 413, Box 10).

See generally Robert A Stein, In Pursuit of Excellence: A History of the University of Minnesota Law School (St Paul, Minn: Mason, 1980).

Anthony Chase, "The Birth of the Modern Law School" (1979) 23:4 Am J Leg Hist 329; John Henry Schlegel, "Between the Harvard Founders and the American Legal Realists: The Professionalization of the American Law Professor" (1985) 35:3 J Leg Educ 311. Elsewhere Schlegel argues, "For the first twenty years of the century, if not longer, Ames's vision of professional role, embroidered in dozens of slightly different variations, but almost always emphasizing an ideal of detailed, systematic, sustained, and comprehensive works of scholarship on the German grand scale, formed the core of the identity of the professional law teacher" (Schlegel, American Legal Realism, supra note 6 at 27). 
Like the University of Alberta, Faculty of Law, Minnesota law students took torts, contracts, property, and criminal law in first year, and in large part the selection of upper year courses - among them, evidence, constitutional law, agency, sales, practice, wills, jurisprudence — was also the same. Within that largely shared curriculum, many of the cases and texts studied - Williston's The Law on Contracts, Thayer's Cases on Evidence, Ames' Cases on Partnerships, to name just a few — puzzled, delighted, and bored students in Canada and the United States alike. There were notable differences of course - English cases played a larger role in Canadian legal education, and obviously Canadian and American constitutional documents, criminal codes, and other statute law remained distinct. Yet for all of their basic similarities, the scale of the enterprise clearly set Minnesota and Alberta apart. When Bowker arrived, Minnesota boasted a dozen or so full-time faculty and a student body of nearly one thousand, all working out of a large dedicated building equipped with a spacious and impressive library. More than that, with Fraser at the helm of the deanship, Minnesota had gone well beyond parroting Harvard, and had set its own distinct and influential course in American legal education.

Everett Fraser is not a well-known figure in the history of American legal education, perhaps because as an administrator, rather than a scholar, he wrote his legacy in sand. When a new tide of ideas and personalities washed the beach over, Fraser and his Minnesota Plan quickly faded from view. Fraser, one of six children, was born on a small farm near North Lake, Prince Edward Island in 1879, his grandparents having emigrated from Scotland early in the century. ${ }^{85}$ "We lived on that farm in much the same way as I suppose my ancestors lived in Scotland," Fraser matter-of-factly explained of his background. "We produced almost everything that we used, and used almost everything that we produced.... The farm produced a mere living, and I had to make my own way through college and law school. But enough of that." 86 The last remark was telling. Fraser was no sentimentalist - he was driven, no nonsense, and ambitious.

Leaving behind the farm and rural schoolhouse, Fraser completed high school at the top of his class at Prince of Wales College in Charlottetown. He taught there for three additional years before he saved enough money to attend Dalhousie University. ${ }^{87}$ After graduating with his B.A. in 1907, Fraser ventured to Harvard Law School, followed two years later by another ambitious and scholarly Maritimer, Ivan Rand. ${ }^{88}$ The Harvard Fraser attended in the

Fraser to Charles Fowler (19 October 1944), Minneapolis, University of Minnesota Archives (Box 1, No 722, Everett Fraser Papers). See also Stein, supra note 83 at 73. Hard work, determination, and success ran in the family. Everett's older brother, J Fred Fraser, became a prominent businessman and politician in Halifax, Nova Scotia. A Conservative, Fraser served briefly in Nova Scotia's cabinet in the 1920s, and later as chair of the Nova Scotia Power Commission, in addition to holding directorships in several successful businesses. "[P]ossessed of a tremendous driving force," his obituary claimed, "Mr. Fraser had the power to organize and execute immense undertakings." "Hon. J. Fred Fraser, Prominent Nova Scotian Citizen, Passes Away," Halifax Herald (5 November 1942) 3. In turn, Everett Fraser's son, Donald Fraser, would go on to serve in the Minnesota Senate, the United States House of Representatives, and as the Mayor of Minneapolis. Fraser to Charles Fowler (19 October 1944), Minneapolis, University of Minnesota Archives (Box 1, No 722, Everett Fraser Papers).

87 Fraser to Vance (21 April 1917), Minneapolis, University of Minnesota Archives (Box 1, No 722, Everett Fraser Papers).

$88 \quad$ Fraser and Rand met and became friendly at the Canada Club housed at 12 Oxford Street, although they did not stay in touch. See Fraser to Rand (9 August 1946), Minneapolis, University of Minnesota Archives (Box 1, No 722, Everett Fraser Papers): "Our paths have not crossed since that year at 12 Oxford Street, which I often recall with pleasure. I was pleased when I heard of the high distinction that you have attained in your native land." On Rand's Harvard years, see William Kaplan, Canadian 
final years of Dean James Bar Ames's deanship had solidified its position as the leading law school in the United States. Fraser excelled in his studies - Harvard's large classes and competitive atmosphere more than suited the self-reliant Fraser. Offering Professors Samuel Williston and Joseph Beale as references, Fraser earned a teaching position at George Washington University Law School directly following his graduation in 1910. Teaching 12 to 14 hours a week on an array of private law subjects - property, sales, corporations, and conflicts - Fraser relied upon his quick intelligence and previous teaching experience to immediately impress in the classroom. ${ }^{89}$ Within four years, and still in his early thirties, he had become Dean. Although Fraser failed to establish himself as a serious scholar - he candidly admitted to having "made no attempt at publication of anything worth mentioning" - his administrative and teaching acumen drew the attention of Minnesota's Dean William Vance, himself a former Dean at George Washington (Fraser was hired the year Vance left for a position at Yale). ${ }^{90}$ When Ernest Lorenzen left Minnesota for Yale in 1917 he recommended Vance hire Fraser as his replacement. Vance did. And when Vance returned to Yale three years after that, he recommended that the Board of Regents appoint Fraser as Minnesota's next dean. ${ }^{91}$ They did. Fraser would hold the position for the next 28 years.

In the early years of his deanship, Fraser managed many of the usual challenges of leading a law school: recruiting and retaining faculty, balancing budgets, navigating the sometimes tricky relationship between the university and the profession, and seeking the procurement of a new and larger law school building. He continued to teach, largely property, with occasional publications in that field, ${ }^{92}$ but as Fraser's administrative experience accumulated, he began thinking increasingly ambitiously and creatively on the place and purpose of legal education. Clearly influenced by his friendship with Pound and progressive era politics more broadly, Fraser turned the insights of Pound's sociological jurisprudence to the law school

Maverick: The Life and Times of Ivan C. Rand (Toronto: University of Toronto Press for the Osgoode Society for Canadian Legal History, 2009) at 13-16. After turning down the deanship at Dalhousie Law School in 1914, Fraser recommended Rand: Stanley Mackenzie to Fraser (19 June 1914 and 3 July 1914), Minneapolis, University of Minnesota Archives (Box 1, No 722, Everett Fraser Papers).

$89 \quad$ "The success of his first year's experience as a teacher of law surpassed by far all my expectations. It was nothing less than extraordinary from the very beginning.... Mr. Fraser has not only a keen intellect, a very thorough knowledge of the law and pedagogic skill of high degree, but possesses, at the same time, great personal charm.” Ernest Lorenzen to Vance (27 April 1917), Minneapolis, University of Minnesota Archives (Box 1, No 722, Everett Fraser Papers). See also Fraser to Vance (21 April 1917), Minneapolis, University of Minnesota Archives (Box 1, No 722, Everett Fraser Papers).

90 Fraser to Vance (21 April 1917), Minneapolis, University of Minnesota Archives (Box 1, No 722, Everett Fraser Papers).

91 Coffman to Fraser (22 July 1920), Minneapolis, University of Minnesota Archives (Box 1, No 722, Everett Fraser Papers). Fraser's starting salary was $\$ 6,500$ per annum; it was $\$ 10,000$ by 1928 . See also Stein, supra note 83 at $73-74$.

92 Stein is too generous, I think, in labelling Fraser "a scholar ... of the first order," Stein, supra note 83 at 74. Although Fraser clearly possessed a sharp intellect and was a fine writer, his small output and largely local focus - no doubt a function of having given over his career to administration - prevented a serious and influential career as a property scholar. Nonetheless, his significant publications include: Everett Fraser, "Title to the Soil Under Public Waters: A Question of Fact" (1918) 2:5 Minn L Rev 313; Everett Fraser, "Future Interests in Property in Minnesota" (1919) 3:5 Minn L Rev 320 \& "Future Interests in Property in Minnesota II" (1920) 4:5 Minn L Rev 307; Everett Fraser, "The Rules Against Restraints on Alienation, and Against Suspension of the Absolute Power of Alienation in Minnesota" (1924) 8:3 Minn L Rev 185 \& "The Rules Against Restraints on Alienation, and Against Suspension of the Absolute Power of Alienation in Minnesota" (1924) 8:4 Minn L Rev 295 \& Everett Fraser, "The Rules Against Restraints on Alienation, and Against Suspension of the Absolute Power of Alienation in Minnesota" (1925) 9:4 Minn L Rev 314. 
itself. ${ }^{93}$ If, in Pound's words, the law as an agent of social progress "must be overhauled continually and refitted continually to the changes in the actual life which it is to govern," then law schools, as producers of both legal knowledge and the law's practitioners, Everett reasoned, must change too. What began as Everett's concern about the low quality of students that law schools admitted (a constant theme in the early hand-wringing of the American Association of Law Schools (AALS)), ${ }^{95}$ grew into a much larger critique of the purpose, design, and underlying ethic of American legal education. Two years into his deanship, Fraser sounded a Poundian and progressive era note, complaining that " $\mathrm{t}]$ he law and its administration have not kept up to the necessities of changing conditions." ${ }^{96}$ Fraser's inchoate notion that something needed changing was sharpened by his experience on Minnesota's Crime Commission in 1926. In public hearings and committee deliberations, Fraser grew increasingly dismayed by what he perceived as conservative responses among Minnesota's legal profession to any degree of proposed change in the criminal justice system. ${ }^{97}$ Out of Everett's frustration, his faith in progressive statism, and his enthusiasm for the capacity of elite lawyering and social engineering, the outline of the Minnesota Plan was born.

On 3 February 1930, the same day that conservative Chief Justice William Howard Taft's failing health caused him to step down from the United States Supreme Court, Fraser proposed his progressive "experiment" in legal education to the University of Minnesota's President. ${ }^{98}$ Fraser advocated a new model which lengthened law school by one year, expanded the curriculum, and shifted the underlying focus of legal education. The existing practice, Fraser complained, of over-emphasizing private law and highlighting the lawyer's singular service to individual clients, had created a conservative profession unable to adapt the legal system to a changing world of new technologies and an expanding role for government in daily life. "[O]ur law schools have been nothing more than vocational training schools," he critiqued. "They have given the information and skills necessary to enable the lawyer to serve his client. They have not given the information, skill or interest necessary to enable the lawyer to serve the state through improvement in the administration of justice." 99 To the existing three-year LL.B. program, Fraser envisioned an additional year devoted "to subjects which are not strictly vocational, but which are cultural for lawyers[:] ...

93 "It is of the utmost importance," Pound wrote to Fraser, "that those of us who are charged with the administration of the more important law schools in the country stand to our guns.... Certainly you have achieved great things at Minnesota, and even if you do not write anything, your influence upon the law and the bar of a great state will in the end be a more solid result and do more for the advancement of justice than is likely to be done by a series of articles in our legal periodicals or a text book." Pound to Fraser (14 March 1928), Minneapolis, University of Minnesota Archives (Box 1, No 722, Everett Fraser Papers). 94 Roscoe Pound, Interpretations of Legal History (New York: Macmillan, 1923) at 1. See also Roscoe
Pound, "The Scope and Purpose of Sociological Jurisprudence I" (1911) 24:8 Harv L Rev 591 \& "The Scope and Purpose of Sociological Jurisprudence II" (1911) 25:2 Harv L Rev 140 \& "The Scope and Purpose of Sociological Jurisprudence III" (1912) 25:6 Harv L Rev 489.

95 See Everett Fraser, “Academic Training for the Bar" (1927) 11:6 Minn L Rev 582. See also Warren A Seavey, "The Association of American Law Schools in Retrospect" (1950) 3:2 J Leg Educ 153.

Quoted in Stein, supra note 83 at 101.

97 Interview of Maynard Pirsig (15 November 1977), Minneapolis, University of Minnesota Archives (Law School Papers, 413, Box 10) [Pirsig Interview]; Stein, ibid at 102. The 1927 Report, its conclusions tentative, is available online: see Minnesota Crime Commission, Report of the Minnesota Crime Commission (Minneapolis: Minnesota Law Review, 1927), online: <http://archive.leg.state. mn.us/docs/2008/other/080896.pdf>.

98 Fraser to Coffman (3 February 1930), Minneapolis, University of Minnesota Archives (Law School Papers, 413, Box 10). Ibid. 
administration of law, legislation - its theory, function and methods, comparative law, legal history, jurisprudence or the philosophy of law, criminology, penology." "[T]his program," Fraser concluded,

would produce a type of lawyer superior to any we have known in the United States. He would have a broader vision. He would see law as a phase of human relations varying in time and place. His interest in the public aspects of his profession would increase as he came to appreciate better the place of law and courts in society. His acquaintance with other legal ideas and systems would give him a flexibility of mind now too often lacking. He would develop a philosophy of law that would give him a sense of direction in his professional activities. $^{100}$

Elaborate and expensive change was not required to implement the vision, Fraser stressed (and here one imagines President Coffman exhaling in relief). Fraser had no quibble with current teaching practices, although clearly his new courses could not proceed on the basis of the case method alone. All he really needed, Fraser argued, was a small budgetary increase to hire the new faculty necessary to teach the proposed subjects.

But inertia is a powerful force in universities as in physics, and Fraser knew to succeed he must build and defend the case for change. Fraser had the strength of his conviction and, by all accounts, his convictions ran strong. Incisive, direct, and forceful — the same qualities that vaulted him from a rural PEI schoolhouse to Harvard to Minnesota's deanship — Fraser was not easily deterred. As his future colleague, Maynard Pirsig put it, Fraser "was one of the most powerful personalities you could meet... You didn't argue with him." " Fraser also had personal capital to spend, having successfully represented the University in State ex rel. University of Minnesota v. Chase two years earlier, ${ }^{102}$ which "guaranteed the University a position of independence within the state's administrative system." ${ }^{103}$ With the Minnesota Plan, Fraser sought to collect on his accumulated goodwill with the University. When the Board of Regents grew nervous when some in Minnesota's legal community expressed skepticism of the plan, Fraser solicited letters of support from leading members of the bar and bench to counteract them. ${ }^{104}$ Fraser's lobbying worked and the University agreed to allow the Minnesota Plan to set the law school on a new course.

But a vision only gets you so far, and Fraser needed professors with particular expertise to bring the Minnesota Plan to life. Over the ensuing years, he recruited a number of young new professors and charged them with developing the curriculum's new fourth year courses. The curricular additions focused overwhelmingly on public law. A strong supporter of

Ibid.

Pirsig Interview, supra note 97. Even in tribute, admirers acknowledged that Fraser's personality could intimidate:

In his home and at social gatherings his warmth, charm and honest friendliness [were] manifest. At the law school and in University and professional meetings, however, his intense dedication to excellence in teaching and to the improvement of legal education made him seem grim and forbidding to most students, colleagues and lawyers. He was an almost terrifying first-year teacher in his implacable insistence on a correct understanding of the intricacies of traditional real property concepts (quoted in Stein, supra note 83 at 73).

220 NW 951 (Minn 1928). The case determined that the University was exempt from state oversight by the State Commission of Administration and Finance.

Stein, supra note 83 at 76. At retirement, the university was still lauding Fraser as the "defender of the University's independence": "Ex-'U' Law Dean Retired at 68: Now He's 82, and Carries Full-Time Teaching Load," Minneapolis Sunday Tribune (6 April 1958) 4.

Stein, ibid at 105 . 
Roosevelt's New Deal, Fraser followed in the main the progressive view of Lochner as a distortion of the Constitution, and supported widespread government intervention in social and economic matters. "We get buried in precedents and rules of law and forget the fundamental principles which underlie them," Fraser argued in a letter defending his political orientation:

The lawyer should not test every new idea by the touchstone of past rules or conceptions. In today's complex society, the lawyer should consider these problems from a social and economic point of view. If new ideas, needed under present conditions, can be admitted within the scope of the Constitution, so much the better. If the Constitution specifically denies them, then the lawyers' efforts should be to have the necessary changes made in the Constitution. ${ }^{105}$

To train lawyers to embrace, rather than resist, systemic legal change, Fraser called upon Maynard Pirsig, the 1925 Minnesota law graduate he had recently hired, to create a new fourth-year course called Judicial Administration. ${ }^{106}$ Fraser found funds to send Pirsig to Harvard in 1931 to study with Pound and Frankfurter for the year, and then to London for another year to observe and study English legal procedures. ${ }^{107}$ Pirsig returned from his remarkable two years of informal study with a course that challenged students to conceptualize and evaluate the judicial and administrative systems, as well as the legal profession as a whole: their features, attributes, deficits, and prospects. As Pirsig explained, "Its purpose was to bring to the students' attention some of the deficiencies and problems of the administration of justice so that as future lawyers they might be more ready and prepared to deal with them and to support the necessary measures for improvement." ${ }^{108}$ At least that was Pirsig's and Fraser's ambitious objective.

As Pirsig later acknowledged, initially the course was "met with considerable student resistance. The subject was not on the list of state bar admission examinations, and students felt no need for a course which looked like one designed for their uplifting." 109 Indeed, student Warren Blaisdell, President of the Student Editorial Board of the Minnesota Law Review, claimed to speak for many in the lengthy missive he sent to Fraser complaining of the Minnesota Plan's new curriculum. Pirsig's course, Judicial Administration, he lambasted, "is meaningless and useless. It contains practically nothing in addition to what is common knowledge. It abounds in generalities and high sounding platitudes. It is also overburdened with statistics, which prove, or tend to prove, absolutely nothing but Mr. Pirsig's running broad statements." ${ }^{110}$ Part of the initial criticisms of the course from students may have traced back to the impetus for the Minnesota Plan in the first place: Fraser's frustration with

Fraser to Clarence E Martin, President of the American Bar Association (22 March 1935), Minneapolis, University of Minnesota Archives (Box 1, No 722, Everett Fraser Papers).

Fraser initially approached Pirsig to temporarily fill in for an absent professor. In Pirsig's words: "Fraser called me up one day and said Fletcher is ill in the middle of a course in suretyship. Do you want to take it over next week? I said well, I've never had the course. He said neither have the students." Pirsig Interview, supra note 97.

Ibid; Stein, supra note 83 at 109.

Maynard E Pirsig, “A Course in Judicial Administration” (1945) 30:3 Iowa L Rev 387 at 387 [Pirsig, "Judicial Administration"]. "It was part of a broader program," he elaborated, "introduced by the addition of the fourth year in which the students' minds were to be directed to the broader implications of the legal system over and beyond the technical services rendered by lawyers to clients" (ibid). Ibid at 392 .

Warren E Blaisdell to Fraser (15 June 1938), Minneapolis, University of Minnesota Archives (Law School Papers, 413, Box 10). 
lawyers, a mindset he had imprinted on Pirsig. "[T]he regrettable fact remains," Pirsig claimed, echoing Fraser, "that practically all measures for the improvement of our courts and procedure meet with the dead weight of ignorance, lack of interest, misconceptions and false fears on the part of the large majority of the legal profession." 111 Peddling the backwardness and obstinacy of the legal profession can be a difficult position to advance in a room of students seeking to become lawyers. Notably, when Pirsig published his course materials, Cases and Materials on Judicial Administration, in 1946, his introduction suggested a different set of rationales for the course. Lawyers should concern themselves with the efficient administration of justice, he now argued, in order to ensure lawyers retain their profitable monopoly on solving business conflict and secondly, to pursue good democratic governance as bulwark against the criticisms of communists. ${ }^{112}$

The course itself covered a miscellany of topics — legal theory, administrative law, the doctrine of precedent, and the organization of the courts, judiciary, and legal profession expressed in edited readings and a handful of cases (the course book stretched to over 1,000 pages). Pound's work was particularly prominent throughout, but the work of realists such as Charles E. Clark, Max Radin, and Herman Oliphant appeared too, although not nearly enough to appease one of realism's leading figures. Jerome Frank left the volume "disappointed," he wrote, largely on account of Pound's clear influence, and relatedly because the text had steered clear of embracing an explicit realist perspective, especially by omitting "any comprehensive material showing the effect of the 'personality' of the trial judge on his findings of fact." " Other reviewers came away more impressed. Esther Lucile Brown, in particular, lauded the course in her survey of all that was right and wrong in American legal education, Lawyers, Law Schools and the Public Service. ${ }^{114}$ And although not as realist as Frank would have wanted, the course did break new ground in its overall ethic of legal reform rather than the substantive transfer of doctrine or procedure, and in its movement away from appellate cases as the singular basis for teaching material. Even students eventually seemed to come to accept the course on its own terms, at least insofar as Pirsig was concerned. ${ }^{115}$

Fraser's second key addition was Horace Read, a fellow Canadian. Having taken a leave of absence from teaching law at Dalhousie Law School to complete his S.J.D. at Harvard under one of Fraser's old mentors, Joseph Beale, Read had earned notice for his work in

Pirsig, "Judicial Administration," supra note 108 at 387.

Maynard E Pirsig, Cases and Materials on Judicial Administration (St Paul, Minn: West, 1946) at vii, citing The Honorable John J Parker, "Improving the Administration of Justice" (1941) 27:1 ABA J 11. "The course at the University of Minnesota Law School, and hence these materials," Pirsig acknowledges "had their inception in the vision and inspiration of Dean Everett Fraser and Professor Wilbur H. Cherry" (ibid at ix).

113 Jerome Frank, Book Review of Cases and Materials on Judicial Administration by Maynard E Pirsig, (1947) 56:3 Yale LJ 589 at 592. On Frank's dispute with Pound during this period, see Daniel R Ernst, Tocqueville's Nightmare: The Administrative State Emerges in America, 1900-1940 (New York: Oxford University Press, 2014) [Ernst, Tocqueville's Nightmare].

114 Esther Lucile Brown, Lawyers, Law Schools and the Public Service (New York: Russell Sage Foundation, 1948) at 137-38. Similarly, a positive review in the Columbia Law Review praised the text and the course for seeking "improvement of judicial administration and the more efficient working of our democratic system," and hoped "this excellent collection of cases and materials will induce many law schools" to initiate similar courses (Will Shafroth, Book Review of Cases and Materials on Judicial Administration by Maynard E Pirsig, (1947) 47:2 Colum L Rev 333 at 335).

115 "[A]s reports began to drift back from graduates that the subject had important value to them as practitioners," Pirsig noted, "such student resistance as existed largely disappeared." Pirsig, "Judicial Administration," supra note 108 at 392. 
conflicts of law and legislative processes. Read's expertise fit perfectly with Fraser's need and he joined the Law School in 1934. Fraser asked Read to develop a new course, simply called Legislation, premised on building skills in interpreting and drafting legislative materials, and assessing and debating their role in democratic governance. ${ }^{116}$ In the published course materials which first appeared in 1948, Read and his co-editor counselled that exposure to "legislative methods should not be postponed until after the students' techniques have become too rigidly set in the "common law' mold." 117 In viewing statutes as representing a fundamentally distinct but ultimately progressive and productive way of thinking about law, Read placed himself at the fore of developments in American legal education. Although the transition had been a long time in the making — Pound and Ernst Freund among others had been writing about the role of legislation in American law for decades $^{118}$ — the arrival of the New Deal hastened law schools in greater numbers to reflect the importance of statute law in the curriculum. Read's casebook clearly bore the imprint of "a decided contemporary flavor" a reviewer noted, referring to its inclusion of extensive material beyond cases: committee reports, book and article excerpts chief among them. ${ }^{119}$ Like Pirsig's course, Read's readings drew on a pastiche of American legal thinkers: Holmes, Pound, Llewellyn, Frankfurter, and Radin. Although, again, Read had not included enough realists to satisfy some. Although impressed with the book's scope, Thomas Imerson complained of Read's "abstract and sterile" take on the subject, and regretted the "absence of the flavor of practical politics and of the clash of social and economic forces" in the course materials. ${ }^{120}$ Taken together, the reviewers hit the mark: Read, like the Minnesota Plan, was simultaneously forward-looking and traditional, bold and cautious.

The battles lines in American legal education in the 1930s had been sharply drawn between the loose collection of functionalists, realists, empiricists, and social scientists first at Columbia and then at Yale, and the equally porous groups of traditionalists, conceptualists, formalists, pragmatists, and sociological jurisprudents at Harvard (and most everywhere else). The dispute - which raged largely in testy articles, divisive faculty politics, and personal correspondence - encompassed several dimensions including the fundamental nature of law (factual and psychological vs. philosophical and historical), the practices of legal research (empirical vs. analytical), and the pedagogies of legal education (craft vs. case method), made all the more trenchant when refracted through the prism of professional ambition, personal antipathies and allegiances, elite institutional competitiveness, and the usual dose of score settling, pride, and hurt feelings. ${ }^{121}$ The legal realists did not like Pound, and he returned the sentiment. The battle has drawn more than its share of attention in the literature on American legal education from the period, largely on account of the prominence

116 Brown, supra note 114 at 222.

117 Horace E Read \& John W MacDonald, Cases and Other Materials on Legislation (Brooklyn: Foundation Press, 1948) at vii. The acknowledgements also recognized both Pound and Fraser for "inspiration and encouragement." The University of Alberta's copy of the text is dated 20 February 1948 and inscribed, "To Wilbur, with the admiration and affection of Horace Read."

118 See Roscoe Pound, "Common Law and Legislation" (1908) 21:6 Harv L Rev 383; Ernst Freund, "Prolegomena to a Science of Legislation: A Report to the Ford Foundation" (1918) 13:3 Ill L Rev 264. See generally, Joseph Dolan, "Law School Teaching of Legislation: A Report to the Ford Foundation" (1969) 22:1 J Leg Educ 63.

119 Robert Kramer, Book Review of Cases and Other Materials on Legislation by Horace E Read \& John W MacDonald, (1948) 36:2 Cal L Rev 344 at 345.

120 Thomas I Emerson, Book Review of Cases and Other Materials on Legislation by Horace E Read \& John W MacDonald,(1949) 58:8 Yale LJ 1414 at 1416.

121 The dramas are well catalogued in Kalman, supra note 6; Schlegel, American Legal Realism, supra note 6; Hull, supra note 6; Ernst, Tocqueville's Nightmare, supra note 113. 
of the scholars engaged, the hold legal realism has attained in American legal philosophy, and the prestige and influence of the Ivy League schools involved. Certainly the personal connections linking Fraser, Pirsig, and Read to Pound ensured that at the Minnesota Law School, the sharpest edges of legal realism were regarded with wariness, if not suspicion. ${ }^{122}$ When Read mentioned a possible job candidate to Fraser who prided himself "on taking a so-called functional approach," Fraser curtly replied that "[he] would not fit here." 123

Read, by contrast, fit just fine. His careful, sometimes staid, doctrinal scholarship in conflict of laws (he had, after all, studied under the reliably conservative Beale at Harvard, one of the realists' chief scholarly targets) and serious manner mirrored Fraser's own approach. ${ }^{124}$ But it would be wrong to view Read and, by extension, the Minnesota Plan, simply in relation to a scholarly dichotomy between modern and traditional that did not really exist. Outside of the corridor of the Yale-Harvard feud, the lines between the various camps, methods, and approaches that so animated the realist-conceptualist divide, while not entirely irrelevant, faded from salience. More often than not, law teaching in the 1930s was a syncretic blend of influences. Read, for example, admired and assigned John Willis, Canada's most unabashedly realist legal scholar, and included the writings of several realists in his materials. ${ }^{125}$ Moreover, Read's teaching in Legislation leaned closer to Jerome Frank's

When Yale graduate Charles Alan Wright arrived to teach at the University of Minnesota Law School in 1950 he was shocked to discover that legal realism and its tenets were still not accepted wisdom in the Midwest. In a letter to his former teacher, Fred Rodell, he despaired:

Do you suppose that the early missionaries got frustrated and discouraged? If I can find a copy of the Bible, I think I may turn to the New Testament to see, for it would be comforting to know that I am not the first missionary to have the feeling of utter futility. I was spoiled at Yale; since everyone I knew there conceded the ridiculousness of conceptualism, I supposed that that devil had been exorcised, and that legal realism, in greater or less degree, was everywhere triumphant. I couldn't have been more wrong. From morning to night, I fight with my classes, with students in to see me, and with some members of the faculty, and all I get from them is: "What was good enough for Langdell is good enough for me." Or "It's easy to decide cases. You just take the facts and look in the law books and get your answer automatically." (Honest to goodness - I asked the student if he thought the law worked like a slot machine and he said "Yes.") Or I will waste a whole class hour going over all the possible policy ramifications of a case, and problems of that sort in it, and someone is sure to come up after the hour: "Mr. Wright, what is the rule of the case?" I find myself alternating between an eager determination to stand this conceptualism on its ear, and a feeling of why the hell am I wasting my time here.

Wright to Rodell (9 November 1950), cited in Kalman, supra note 6 at 95.

The exchange is revealing of another reality of the 1930s legal academy: pervasive anti-Semitism. At least part of some unspoken hostility towards legal realism may well have been the view that it was associated with East Coast Jewish scholars. "Since writing you confidentially concerning Phillips," Read subsequently wrote, "I have been told by him that he is of the Hebrew race. I had not even suspected the fact, so you can see that he does not display any of the well known characteristics of the race to any noticeable degree. I have no anti-semitic prejudice myself, but as some people consider it a factor to be considered, I pass the word on so that you may have as complete a picture as I am able to give." Read to Fraser (28 June 1934), Halifax, Dalhousie University Archives (Read Papers). "Before receiving your last letter I had decided that Phillips would not fit here," Fraser replied "and your last letter confirms the decision." Fraser to Read (3 July 1934), Halifax, Dalhousie University Archives (Read Papers).

Notably, Read dedicated the publication emerging from his thesis to John Delatre Falconbridge, "scholarly architect of law." Read, Recognition and Enforcement, supra note 73. Falconbridge, one of Canada's leading conflict of law scholars in the first half of the twentieth century, produced widely lauded "straightforward exposition and synthesis of ... doctrine" across an array of private law subjects. In the words of R.C.B. Risk, in his long scholarly career "Falconbridge continued to be committed to the nineteenth-century tradition." RCB Risk, "Canadian Law Teachers in the 1930s: "When the World was Turned Upside Down"” in G Blaine Baker \& Jim Phillips, eds, A History of Canadian Legal Thought: Collected Essays (Toronto: Osgoode Society for Canadian Legal History, 2006) 341 at $352-53$.

125 "I have just finished reading your brilliant article on 'Statute Interpretation in a Nutshell,"' Read wrote to Willis. "It is by far the best treatment of the subject that I have ever read..... I did my best to find something to disagree with, but could find only my own conclusions expressed with more dash than I could muster." Read to Willis (9 February 1938), Halifax, Dalhousie University Archives (Read Papers). Willis replied sheepishly that Read surely recognized "the Thurman Arnold touch — I do not claim any 
ideal clinical law school for lawyers - integrating skills of what "lawyers actually do" than Harvard's pure case method archetype. ${ }^{126}$ Anticipating later developments in clinical education and active classroom learning, Read integrated legislative drafting assignments into class time, even arranging for groups of students to produce draft legislation for state legislators, bar associations, and other interest groups. ${ }^{127}$ Fraser responded with strong faculty support: Legislation was a required four-credit course with 60 classroom hours devoted to it. Although, like Pirsig's experience in Judicial Administration, students did not immediately warm to Read's course either. In the same caustic letter complaining about Pirsig, Blaisdell reserved his strongest scorn for Legislation. "This is absolutely the worst excuse for a course I have ever seen," the student complained, "I am wondering where it got its name. I would suggest rather that it be called 'Tantalizing Trivia' or the 'Inconsequentialist Fact Department.' I have yet to know or hear of a student who didn't finish the course thoroughly disgusted." 128

Stefan Riesenfeld had the most remarkable of the trio's journey to Fraser's team. Born in Breslau, Germany in 1908, he had been teaching law in Germany before taking up a professorship in Milan, Italy to escape the repressive and violent Nazi regime. An encounter with the Dean of Berkley led to his emigration to America and a further law degree from Boalt Hall. A research fellowship with Felix Frankfurter at Harvard followed, paving the way for his hiring at Minnesota in 1938 to teach Modern Social Legislation. ${ }^{129}$ The course examined various New Deal initiatives, labour legislation, minimum wage laws, and social welfare measures from legal, economic, social, and political viewpoints. ${ }^{130}$ Pointing to a history of judicial antipathy to economic intervention by government to pursue social aims, Risenfeld's co-authored course text heralds a postwar world in which the "widespread demand for and advocacy of a universal and integrated social security program" signalled

originality for the approach.” Willis to Read (15 February 1938), Halifax, Dalhousie University Archives (Read Papers). See John Willis, "Statute Interpretation in a Nutshell: Preliminary Observations" (1938) 16:1 Can Bar Rev 1, an excerpt of which is included in Read's coursebook.

126 Jerome Frank, "Why Not a Clinical Lawyer-School?" (1933) 81:8 U Pa L Rev 907 at 913 . See also Karl N Llewellyn, "Lawyer's Ways and Means, and the Law Curriculum" (1945) 30:3 Iowa L Rev 333 ("training in the basic craft-skills of the lawyer is the present pressing need" at 333); Jerome Frank, "A Plea for Lawyer-Schools" (1947) 56:8 Yale LJ 1303.

127 As James Gray enthused in his history of the University of Minnesota, "[Read's] students were put to work at laboratory projects and the results of these investigations into the history of Minnesota statutes were published in the Minnesota Law Review. The importance of these studies was so widely recognized that in the midst of legislative sessions students frequently were called upon by Minnesota lawmakers for rush jobs of analysis with regard to pending legislation" (James Gray, The University of Minnesota, 1851-1951 (Minneapolis: University of Minnesota Press, 1951) at 485-86). Read's course is also detailed and praised in Brown, supra note 114 at 222-26.

128 Warren E Blaisdell to Fraser (15 June 1938), Minneapolis, University of Minnesota Archives (Law School Papers, 413, Box 10). The letter continued, "I profess I do not know what the object of the course is. It certainly cannot be to [imbue] us with a knowledge of Mr. Read's luncheon engagements or his accomplishments, though they occupy a large proportion of the time." Read's course in Conflict of Laws did not fare any better. Here Blaidsell complained of Read "loaf[ing] around, quibbling about words, pointing out split infinitives, and telling sundry unrelated jokes and anecdotes.... The class hour itself is spent in a pleasant informal discussion of anything but Conflicts. The students find Mr. Read's classes ideal for the writing of poetry." There is no record of Fraser's reply, if there was one.

129 For Riesenfeld's biography, see Richard W Jennings, "Stefan A. Riesenfeld: In Tribute" (1975) 63:6 Cal L Rev 1387.

130 In his co-authored course text, Riesenfeld defined social legislation as "programs which are designed to assure any member of society of the means to obtain, without unreasonable effort, all material items, such as food, clothing, shelter and medical services, necessary for a decent minimum standard of living" (Stefan A Riesenfeld \& Richard C Maxwell, Modern Social Legislation (Brooklyn: Foundation Press, 1950) at 2 [emphasis in original]). The text is dedicated "To Everett Fraser Dean emeritus of the University of Minnesota Law School Pioneer in Legal Education” (ibid). 
the arrival of a new "political philosophy" of government. ${ }^{131}$ The course proceeded not only from a changed notion of government but of law teaching itself. As Riesenfeld explained, "[i]n my course on Modern Social Legislation, the use of 'extra legal materials' (improperly so called) looms large." ${ }^{132}$ Certainly, Risenfeld's course book reflected his catholic approach to the subject, with particular attention to economic context, and contained more expansive explanatory notes and introductory comments than appeared in the corresponding materials of Pirsig or Read. Together, Judicial Administration, Legislation, and Modern Social Legislation, formed the heart of the Minnesota Plan's new curriculum.

By 1935, in the pages of the Canadian Bar Review, Fraser was already pronouncing his "experiment" in legal education a success. To bolster his claims, Fraser pointed to the high pass rates of Minnesota's students on state bar exams. Although other law schools had been seeking advice on how to implement similar changes, for the most part, the Plan's achievements remained mostly couched as aspirations. "The lawyer who has large conceptions of the nature of law, its causes and its functions, who sees the binding threads of principles running through it," Fraser argued, "is better equipped to serve his clients and society than the lawyer who regards rules of law as static unrelated matters." ${ }^{\prime 133}$ Moreover, a handful of other law schools, including the University of Chicago Law School, had similarly moved to embrace a four-year optional or mandatory curriculum. ${ }^{134}$ As Wilber Katz at Chicago explained, "the most striking feature of our plan is in the incorporation of subjects such as economics, political theory, and psychology." ${ }^{135}$ But not even the imitation of others, the force of Fraser's faith, or his powers of persuasion could convince all. William Prosser, Minnesota's resident tort expert and among the nation's leading private law scholars, remained, in his own words, a "lone wolf" in criticizing the practical utility of the new curriculum. ${ }^{136} \mathrm{He}$ may not have been as alone as he suspected. Some students, as we have seen, complained bitterly about the necessity of extending their legal education by an additional costly year, while others seemed annoyed by the course content, its underlying politics, or both.

Fraser remained steadfast. Elected President of the AALS in 1944-45, Fraser surveyed the changing landscape across America's university-based law schools. ${ }^{137}$ While still suspicious of legal realism as a legal philosophy, Fraser nonetheless approved of the manner in which realism's underlying assumptions about the centrality of facts, lower court judgments, judicial politics, and extra-legal materials had worked their way cautiously into teaching practices and course materials. What occurred was not a revolution, but the quiet absorption of realism into existing modes of legal knowledge and teaching. Courses in jurisprudence appeared across the curriculum with greater regularity and with greater attention to contemporary thinkers, dilemmas, and contexts. And public law offerings in

Ibid at 4 .

Memorandum from Riesenfeld to Pirsig (15 November 1951), Minneapolis, University of Minnesota Archives (Law School Papers, 413, Box 10).

Everett Fraser, “A Minnesota View of Legal Education” (1935) 13:6 Can Bar Rev 414 at 415.

See Alfred Harsch, "The Four-Year Law Course in American Universities" (1939) 17:3 NCL Rev 242.

Wilbur G Katz, “A Four-Year Program for Legal Education” (1937) 4:4 U Chicago L Rev 527 at 527. William Prosser, "The Curriculum: A Sub-Minority, or Lone Wolf, Report" (Spring 1940), Minneapolis, University of Minnesota Archives (Law School Papers, 413, Box 10).

As Brown reported, "In most of the schools visited at the turn of the decade at least one new course was being given or was under consideration.... Generally speaking, these courses represented a radical departure from the traditional curriculum and from anything that had been offered in the particular school previously." Brown, supra note 114 at 134. 
administrative law, labour law, and legislation dotted more than just Minnesota's course offerings, although few schools had gone as far as Minnesota in attempting to weave public service into the fabric of the law school's purpose. For committed realists of the period, such developments seemed half-hearted and marginal, but, in the main, legal scholars and law deans believed themselves part of a period of tremendous "ferment" and change in both the curriculum and teaching methods of legal education. ${ }^{138}$

If Fraser took some comfort in these developments, he did not reveal them in his concluding address as AALS president. Instead he pushed law schools to go still further in placing public service and the administration of justice alongside service to the client as fundamental goals of modern legal education. At its core, Fraser's view of legal education remained premised on a particularly elite driven conception of democracy, a powerful faith in the ability of lawyers to deliver and administer public goods, and a supreme confidence in legal education itself. "In a democracy," Fraser argued, "no class is specially designated for leadership, but lawyers, because of their knowledge of existing institutions and laws are naturally expected to lead." "Law students should be taught," Fraser insisted, "that a lawyer is not a mere journeyman working according to rules given him by others, but is a social engineer, who designs the machinery of government and formulates the rules for its operation, who examines new ideas, incorporates the good ones into the design, watches for stresses and strains, and provides the remedies, all with the object of attaining a more perfect justice." "Our law schools have been pointing students for careers as business advisers rather than as professional statesmen." 139 And yet the impetus for the Minnesota Plan in the first place had been Fraser's conviction that law school could educate students better than anywhere else within the University. "For mental discipline," Fraser asserted earlier in his career, "the law course is the best in the university." ${ }^{140}$ For all of his years critiquing the legal profession, Fraser's vision for legal education was founded on a supreme confidence in law professors delivering extra-legal perspectives in which they had not been trained, in law schools inculcating high-minded idealism, and, ultimately, in lawyers delivering on the social promise of a better world.

To be sure, Fraser's vision of legal education drew heavily on his formative progressive era faith in experts (lawyers) and expertise (legal training) to remake a broken world. For his part, Read traced Fraser's vision back to Fraser's days at Dalhousie University and the public spirit that animated Dalhousie Law School during the deanship of Richard Chapman Weldon (1883-1914). ${ }^{141}$ Weldon, who served as a Member of Parliament while dean, "preached the duties of lawyers to the state in all branches of public service. It was the duty of lawyers to take part in the political life of the country ... but always to keep in mind the higher duty of cleansing and purifying it from within."

Albert J Harno, Legal Education in the United States: A Report Prepared for the Survey of the Legal Profession (San Francisco: Bancroft Whitney, 1953) at 180.

139 "President's Address" [nd], Minneapolis, University of Minnesota Archives (Box 1, No 722, Everett Fraser Papers). The remarks were drawn from Everett Fraser, "Legal Education" (1944) 231:1 Annals American Academy Political \& Social Science 92 at 92-94.

140 Fraser, "Integrated Course," supra note 81 at 717.

141 Read to Macdonald (30 January 1950), Halifax, Dalhousie University Archives (Read Papers). Some of Read's analysis should be taken with a grain of salt considering the purpose of his letter: to nudge Dalhousie into awarding Fraser an honorary doctorate.

142 Willis, History of Dalhousie Law, supra note 6 at 9, citing John Barrett, "Dalhousie Law School: Ideals and Traditions" (1907) [unpublished]. 
Dalhousie Law School, but, given his ambitions, he would have been well aware of the law school during his time at Dalhousie and we know he maintained close enough ties to Dalhousie to have been offered the deanship of the law school when Weldon retired. ${ }^{143}$ Fraser's politics played a role in cementing his vision of legal education too. From a conservative Canadian maritime upbringing he inherited a strong identification with the justness of the British Crown and Commonwealth, ${ }^{144}$ which he translated in his American experience into strong support for progressive era policies, Roosevelt's administration, and the New Deal specifically. ${ }^{145}$ Fraser's politics were underpinned by a deep attachment to government institutions, legal order, and the state more broadly. At the institutional level, Fraser stressed that he viewed matters on legal education "from the point of view of a state university ... where the state pays two-thirds of the cost [of a student's education], the people's interests must be kept in mind." "146 But the Minnesota Plan was also the product of a particular time of searching in American legal education.

"That law teachers all over the country are with obvious concern planning a revision of the methods and substance of their teaching," Max Radin dryly observed in the early 1940s, "is a sign of something or other." ${ }^{147}$ In truth, as Radin himself pointed out, American legal education had never really been static. But the intellectual vibrancy of legal realism combined with the institutional concerns about professional status expressed by the American Bar Association and the AALS, set against the backdrop of the societal and governmental transformations occasioned by the Depression and then the Second World War produced a singular moment of introspection about the purpose and methods, ethics and structure of American legal education. Equally, the scholarly catalysts of sociological jurisprudence and then legal realism demanded that their intellectual innovations translate into pedagogical practices.

Fraser and the Minnesota Plan had been ahead of this curve by nearly a decade. But just as legal transplants necessarily involve adaptation to new surroundings, ideas in legal education take unique shape in their particular institutional contexts. Fraser was not the first or the last to place the idea of public service at the core of legal education's mission and identity, ${ }^{148}$ but his personality, administrative experience, and supportive institutional context

Mackenzie to Fraser (19 June 1914), Minneapolis, University of Minnesota Archives (Box 1, No 722, Everett Fraser Papers).

Fraser to Headley (13 November 1943), Minneapolis, University of Minnesota Archives (Box 1, No 722 , Everett Fraser Papers), noting his "familiarity with and admiration for the gradualism of the common law and of British institutions.... [In Canada] I was an ardent imperial federationist."

145 Courtney to Fraser (29 May 1937), Minneapolis, University of Minnesota Archives (Box 1, No 722 , Everett Fraser Papers), in which Courtney laments Fraser supporting Roosevelt's court packing plan.

146 Fraser, "Integrated Course," supra note 81 at 714. As Eric Sevareid wrote of his alma mater in the 1950 s, "I know of no state university which belongs so unquestionably to the state, none which the people of the state so instinctively regard as part of their individual and corporate lives.... It feeds back into the state at least as much as it receives," quoted in Stanford Lehmberg \& Ann M Pflaum, The University of Minnesota: 1945-2000 (Minneapolis: University of Minnesota Press, 2001) at xv.

147 Max Radin, "The Dilemmas of Legal Teaching" (1945) 30:3 Iowa L Rev 355 at 355.

148 In his tribute to Wesley Hohfeld, Walter Wheeler Cook credited his Yale colleague for pushing law schools "to awake and do their full duty in the way of training men, not merely for the business of earning a living by 'practicing law,' but also for the larger duties of the profession, so that they may play their part as judges, as legislators, as members of administrative commissions, and finally as citizens, in so shaping and adjusting our law that it will be a living, vital thing, growing with society and adjusting itself to the mores of the times" (Walter Wheeler Cook, "Hohfeld's Contributions to the Science of Law" (1919) 28:8 Yale LJ 721 at 738 [emphasis in original]). See also Harold D Lasswell \& Myres S McDougal, "Legal Education and Public Policy: Professional Training in the Public Interest" (1943) 52:2 Yale LJ 203. 
allowed him to do more than most in expanding the law school curriculum, extending the length of training, and articulating a different vision for legal education. But, even with these successes of difference in mind, it is important to observe that Fraser's Minnesota Plan nonetheless took shape in an educational culture of remarkable attachment to its traditions. Law school professors and students alike continued to expect, and often demand, a legal education still largely devoted to private law by the case method of instruction in order to rank their performance for prospective employers. Moreover, although the Minnesota Plan made room for more experimental and active teaching practices such as in Read's Legislation course, Fraser did so by enlarging other lecture courses to conserve resources. ${ }^{149}$ The Minnesota Plan set North American legal education on the path of a more diversified curriculum and alternate teaching methods, but it also financed its ambitions (and its professorate's increasing salaries) on expanding enrollment, and higher student-to-professor ratios. In all of these respects, the Minnesota Plan foretold the future of legal education in North America.

\section{DEAN BOWKER AT THE BAT}

It was very much Fraser's law school, then, that Wilbur Bowker arrived at in the summer of 1946. Indeed, it had been Fraser himself who had personally authorized Bowker's admission to the LL.M. program. ${ }^{150}$ For all the attention Fraser paid to undergraduate legal education, Minnesota's graduate program remained, like most law schools, a haphazard endeavour, and certainly an afterthought. While there had been some movement among the member schools of the AALS to rationalize and justify graduate standards, the graduate programs at most schools remained idiosyncratic, especially for the Master's degree. At Minnesota, the expectation was that Bowker would take a number of advanced law courses and produce a thesis, but beyond that there was no real program. Living with Read that first summer, Bowker immersed himself in his coursework, essentially a crash course in the Minnesota Plan: Administrative Law with Riesenfeld, Jurisprudence with Jerome Hall visiting from Indiana, and Judicial Administration with Maynard Pirsig. ${ }^{151}$ In the subsequent summer, Bowker took Legislation with Read and Constitutional Law with William Lockhart. Read wrote to Bowker after his first summer term to congratulate him on his fine performance, straight “A"s. ${ }^{152}$ Bowker ensured that Read's letter found its way into the hands of both Steer and the President of the University of Alberta. Although the search for a dean at the University of Alberta, Faculty of Law continued during the fall of 1946, it was becoming increasingly apparent that the deanship should fall on Bowker's capable shoulders. When Steer hinted to Read the possibility, Read made his blessing plain: "In my opinion you would go a long way to find his equal, let alone his superior."153

"Rather than to have many indifferent teachers devoting themselves doggedly to groups of forty students," James Gray explains, "it was better, [Fraser] became convinced, to have a smaller number of superior teachers working with two hundred students. Positions ceased to be sacred to him. When one fell vacant he would sometimes surrender it on the promise of being allowed to have the funds to raise the salaries of the men he wished to hold." Gray, supra note 127 at 483 . Read to Bowker (7 May 1946), Halifax, Dalhousie University Archives (Read Papers).

Bowker's course with Hall inspired one of his first scholarly publications, a book review of George Whitecross Paton's A Text-Book of Jurisprudence published in the Canadian Bar Review: (1947) 25:8 Can Bar Rev 931. "And I will say this," Bowker noted, "Minnesota might not have the general reputation that Harvard, Yale and Michigan and Stanford have, or Columbia, but I was awfully fortunate in the instructors I had." Bowker Interview, supra note 11 at 193.

152 Read to Bowker (October 1946), Halifax, Dalhousie University Archives (Read Papers). 
Bowker returned to Alberta a successful graduate student, but yearned to be proven a successful academic. The University of Alberta, Faculty of Law had, in many respects, started anew in 1945 and now, with a year's teaching experience under his belt, fresh with confidence, and invigorated with ideas from his months in Minnesota, no one questioned Bowker's role at the helm. In the winter of 1947, President Newton appointed Bowker Acting Dean and Full Professor, a prelude to Bowker's official appointment as Dean the following year. Bowker continued to teach a large array of subjects, assisted by a small handful of practitioners, including his friend and former law firm colleague, Ronald Martland, teaching administrative law. Under Bowker's leadership, the Faculty expanded its course offerings as best it could given its under-staffed faculty: alongside the traditional curriculum, courses appeared in conflict of laws, bankruptcy, and taxation. Bowker began teaching jurisprudence and, in a nod to Read's influence, the course Recent Cases was retitled Recent Cases and Legislation. ${ }^{154}$ Fraser's broader view of legal education can also be detected in the thinking of George Steer, still actively involved in the affairs of the Faculty of Law, and chair of the CBA's Legal Education and Training Section. In the latter capacity, Steer drafted a report on legal education published in the Canadian Bar Review that bore the distinct imprint of Minnesota's influence. ${ }^{155}$ "[W]e are living in a revolutionary epoch when law and society are bound to undergo and are now undergoing profound change," Steer asserted. ${ }^{156}$ "The lawyer," he continued, "more perhaps than the member of any other learned profession, owes a duty to society to equip himself as a policy maker."157 Citing Pound, Holmes, Cardozo, and Fraser, Steer advocated a system of legal education which emphasized a lawyer's public duties to improve the functioning of the state, to instill the understanding that "law must develop as society does and accord with its views of fundamental relationships." "158

Translating those lofty goals into reality fell largely on the shoulders of Wilbur Bowker. Fraser, after all, had the luxury of new hires, a modestly increased budget, and a relatively large faculty to implement his vision. The budgetary reality in Alberta, and the scarce and in-demand pool of candidates for law teaching across Canada, made Bowker's task more difficult. He continued to rely heavily on his own teaching as well as a small roster of local lawyers. The Faculty did manage to hire one additional assistant professor in 1946, but his quick departure signalled the changing culture of the postwar classroom. Recalling the "disaster," Bowker could not even bring himself to mention his former colleague's name. ${ }^{159}$ What he did stress was that he "had not been in the services," and that "[t]hese veterans didn't like him. He had a rough time." "160 Large numbers of returning veterans transformed university campuses across North America in the years following the war. As Philip Girard points out, "veterans were older, feistier, less deferential than the classes of the pre-war years." ${ }^{161}$ Not even a figure as confident and impressive as Bora Laskin could escape

The University of Alberta Calendar, 1950-51 at 305-13. The Faculty of Law also permitted upper year students to take a number of courses outside of the Faculty, including Legal Psychology, Corporation Finance, Political Science, Public International Law, and Roman Law.

GH Steer, "On Legal Education in Canada" (1947) 25:9 Can Bar Rev 943.

Ibid at 943 .

Ibid at 944

Ibid at 948 .

Bowker Interview, supra note 11 at $187-89$.

Ibid at 187.

Philip Girard, Bora Laskin: Bringing Law to Life (Toronto: University of Toronto Press for the Osgoode Society for Canadian Legal History, 2005) at 155. 
occasional classroom comment for having not served during the war. ${ }^{162}$ But Bowker had served, even if he had not seen active duty, and even if some of his students outranked him. That wartime service, in addition to his genial and lawyerly manner, earned him respect, admiration, and friendship from those early cohorts of students. It was Bowker who personally admitted students during his tenure as dean, freely admitting that his sympathies lay with applicants who had served in the war. ${ }^{163}$ In recognition of their service, Bowker offered veterans greater academic support and extended them wider leeway in the event that support proved insufficient at exam time. ${ }^{164}$ And even when, after a few years, the veterans had largely vanished from the Faculty, Bowker retained the same fundamental approach to new incoming classes. Bowker's law school was one in which the dean knew every student's name, in which a sense of collective experience was fostered, and in which Bowker would embody "a continuous and single-minded devotion to the ideals and values of law and legal institutions as well as a patriotic fervour for Canada and its people." 165

In this largely masculine professional world in which Bowker excelled, he cultivated a series of practices that collapsed the barriers and cemented the bonds between him and his students. He was widely regarded as an exceptional teacher, rigorous in his demands, but also affable and interested in his students, although never overly personal or familiar. ${ }^{166}$ Despite his administrative responsibilities, Bowker continued to teach a number of core courses, including Torts and Civil Liberties, among others. Graduating students, especially in the early years of his deanship, were typically invited to his home for a meal or tea, and he became famous for his prodigious memory: at the graduation ceremony each year Bowker called every student by first and last name without notes. Certainly it was easier for men who shared similar backgrounds and values to get along in the tight social confines that the Faculty of Law fostered under Bowker's leadership. But Bowker also typically admitted a handful of female students each year — including Violet King, the Faculty's first black student ${ }^{167}$ — and by all accounts, doubtless with his wife Marjorie as an important influence, he promoted the inclusion of women in the law school. In other respects, he remained highly protective of what he would have described as the character of the student body. In the most famous and contentious of those battles, one student sued Bowker personally for refusing to admit him. ${ }^{168}$ The case detailed Bowker's admissions practice which included a personal

“"[W]here have these judges been for the last ten years?"” Laskin rhetorically asked his constitutional law class in the late 1940s. "[A]nd where have you been for the last ten years?" someone at the back of the classroom replied (ibid at 155).

163 Bowker Interview, supra note 11 at 168 . Bowker continued to exercise his control over the admissions process throughout his deanship. When Beverly McLachlin, future Chief Justice of the Supreme Court of Canada, wrote to Bowker looking for information on the law school in the summer of 1965, Bowker's letter in reply admitted her to the class beginning in September. Interview of The Right Honourable Beverley McLachlin by Eric M Adams (2 September 2014) [Chief Justice McLachlin Interview]. In his report to the University on the issue of veterans at the Faculty of Law, Bowker noted that "In conjunction with the [Department of Veterans Affairs], every help is given to him in solving any special personal or academic problems. In the case of failure in a course or courses, he is allowed supplementals more freely than he would be under the general rule and where he has done very badly, the facts are examined to see if there are any extenuating circumstances. If so, he may be given a second chance." Wilbur Bowker, "Student Veterans in Law at University of Alberta" (14 September 1948), Edmonton, University of Alberta Archives (68-1 3/4/4/9/1, "General Correspondence", Robert Newton Papers). "In Memoriam: Dean Wilbur Bowker," Edmonton Bar Association Bulletin (Spring 1999) 15. I thank Chief Justice McLachlin and Judge Allan Lefever for sharing their memories of Bowker's teaching from the 1960s with me: Chief Justice McLachlin Interview, supra note 163; Interview of Judge Allan Lefever by Eric M Adams (20 June 2014). See Rachel K Bailie, "Minority of One: Violet King's Entry to the Legal Profession" (2012) 24:2 CJWL 301.

Pecover $v$ Bowker and Governors of the University of Alberta (1957), 8 DLR (2d) 20 (Alta SC). 
interview with the candidate, a review of the student's transcripts, and, in some cases, involved a series of intelligence and personality tests administered by Student Advisory Services. ${ }^{169}$ While the student complained that his unstated political beliefs (presumably communist) played an improper role in the decision, Bowker testified that he never concerned himself with an applicant's political or religious beliefs. Nonetheless, Bowker acknowledged that personality tests were one helpful factor in his decision making, and, in this particular case, the outcomes of those tests supported the decision to refuse admission. ${ }^{170}$ Bowker, in his personal control over the admissions process, was quite prepared to exercise his power to deny entry if he thought that an individual was unsuited to the law school, as well as to the practice of law.

Bowker returned to Minneapolis to take classes in the summer terms of 1947 and 1948, Fraser's last year as Dean. He also began to turn his mind to writing his thesis. The setting made a comparative project attractive, but Bowker also wanted to tackle a topic of current interest. As a lawyer, his firm had been retained by a number of Germans interned outside of Calgary under the Defence of Canada Regulations during the Second World War. Bowker had come away from that experience worried about the secretive nature of the proceedings and absence of due process for his clients. ${ }^{171}$ In the early postwar period, the passage of the Universal Declaration of Human Rights, and domestic rights controversies surrounding the denial of due process during the Gouzenko spy scandal and the dispossession and deportation of Japanese-Canadian citizens, elevated the question of Canada's commitment to human rights and fundamental freedoms to the forefront of political and legal debate. ${ }^{172}$ As pressing as the topic was, the scholarly writing on the topic of Canadian civil liberties was nearly nonexistent, although the field would grow considerably in the ensuing decade. In comparative constitutional law, Bowker found his topic.

“Canada's constitution contains no Bill of Rights," Bowker's LL.M. thesis, Basic Rights and Freedoms in Canada, begins. ${ }^{173}$ Should it? The answer, Bowker reasoned, would lie in a comparative study investigating whether the American approach to constitutional rights protection yielded better outcomes than Canada's adherence to parliamentary supremacy. Over the ensuing 400 pages, Bowker meticulously canvassed the state of civil liberties protection in both countries. His careful, precise, and measured prose marked a writing style

After his interview with the unsuccessful applicant, Bowker directed him to Student Advisory Services where he "took several tests including the Strong (interest inventory test), the Wechsler Bellevue intelligence scale test (Form 1) and the Rorchsach personality test" (ibid at 21).

Ibid at 21-22. While being careful not to impugn the merits of Bowker's decision, the Alberta Supreme Court held that Bowker had exercised the power of admission without proper authorization from the Board of Governors and remitted Pecover's application for admission to them (ibid at 25-26).

171 " $[\mathrm{T}] \mathrm{hree}$ times in the fall of 1939 I went down to this internment camp to try to do something for these people," Bowker remembered, "and I did get a hearing in front of the committee that was screening these things, but ... you didn't know what the case was against these people, and why they were interned.... I concluded that our review procedure wasn't really an adequate review procedure at all.... I got no where. The Committee was nice, there was an Ottawa Judge and a few other people from Ottawa, but I never knew really what the case was against them. It wasn't really any kind of a hearing." Bowker Interview, supra note 11 at 95-96.

172 "One of the most important questions before the Canadian public at the moment," the Canadian Bar Review wrote in 1948, "is the question of human rights and fundamental freedoms": Canadian Bar Review, "The Joint Committee of Human Rights and Fundamental Freedoms" (1948) 26:4 Can Bar Rev 706 at 706. See generally Eric M Adams, The Idea of Constitutional Rights and the Transformation of Canadian Constitutional Law, 1930-1960 (SJD Thesis, University of Toronto Faculty of Law, 2009) [unpublished].

173 Wilbur Bowker, Basic Rights and Freedoms in Canada (Master's Thesis, University of Minnesota Law School, 1952) [unpublished] [W Bowker, Basic Rights and Freedoms]. 
he would retain for the balance of his scholarly career. The work was largely descriptive, but the scale of the endeavor - a comprehensive cataloguing of American Bill of Rights jurisprudence - took tremendous time and effort, especially for a Canadian. He laboured over the work for several years, finally submitting it in 1952. Bowker's conclusions echoed the progressive lean of American constitutional thinking of the period. Rather than a demand for constitutional rights sounding from progressive Canadian law teachers like Frank Scott of McGill, Bowker espoused the wisdom of parliamentary democracy in protecting individual rights. ${ }^{174}$ In keeping with the broad liberal consensus shared by most of his Minnesota teachers, he cited Justices Holmes and Frankfurter in arguing that the robust judicial enforcement of a constitutional Bill of Rights effectively corroded the democratic credentials of legislation and majority rule. "It is not healthy," Bowker concluded, "to leave to the Court the task of trying to remedy Parliament's mistakes. It seems to me that in the United States the wide degree of judicial review has bred in the public a disrespect for legislatures and laws." ${ }^{175}$ Bowker reiterated that view in his handful of publications on the topic and in the course he taught on Civil Liberties beginning in the 1950s. Throughout his career, Bowker retained the essential elements of his concern for civil liberties but opposition to entrenched constitutional rights, including the Canadian Charter of Rights and Freedoms. ${ }^{176}$

As Bowker's deanship entered its second decade, his personality had impressed its influence on the University of Alberta, Faculty of Law in much the same way Fraser's had at the University of Minnesota Law School. But where Fraser had championed the paramountcy of public service, the smaller scale of the endeavour, Bowker's closer ties to his students and, ultimately, to Alberta's still closely-knit bar of practicing lawyers tempered some of the binaries between public and private that Fraser saw laid before him. In 1957, on behalf of the Canadian Association of Law Teachers (CALT), Bowker drafted a Statement of Objectives for Canadian Common-Law Schools. Never adopted, the draft still reveals the faint imprints of Bowker's exposure to the Minnesota Plan. Less forceful, less poetic, and certainly less incisive than Fraser's remarkable writings on the same topic, Bowker's genial statement, like the man himself, sought compromise and balance between the multiple perspectives and various facets of legal education.

"It is recognized that not all teachers will put the same emphasis on one or other of the objectives of law schools," Bowker wrote. "It is not the intention of this statement to be dogmatic about any of them or to prescribe rigid and detailed objectives. There is room for differences of opinion." "177 Certainly, legal education must recognize that a lawyer "bears a measure of responsibility in improving the social order," he surmised, but so too must the lawyer "be equipped to give advice on legal problems and also to take steps to make his (2006) 51:3 McGill LJ 435.

175 W Bowker, Basic Rights and Freedoms, supra note 173 at 421-23.

176 See Wilbur F Bowker, "Protection of Basic Rights and Liberties," in Marjorie Bowker, ed, A Consolidation of Fifty Years of Legal Writings, 1938-1988 (Edmonton: University of Alberta Press, 1989) 162 [M Bowker, Fifty Years of Legal Writings]; Wilbur F Bowker, "Basic Rights and Freedoms: What Are They?" in ibid, 224; Wilbur F Bowker, "A Canadian Charter of Human Rights?" in ibid, 363; Bowker Interview, supra note 11 at 271.

177 Wilbur F Bowker, "A Statement on Objectives of Canadian Common-Law Schools" (1958) 36:2 Can Bar Rev 242, reprinted in M Bowker, Fifty Years of Legal Writings, ibid at 220. 
advice effective." 178 And there was no getting around it: "[s]ince law does consist of rules and doctrine, an understanding of them must remain an important part of the lawyer's training together with a grasp of the doctrine of precedent." "role in social change and in meeting the needs of society," a lawyer must also apply law with an eye to the future. ${ }^{180}$ In other words, a legal education not unlike the Minnesota Plan: public law, interdisciplinary perspectives, and legal theory paired with the traditional curriculum of private law, judicial reasoning, and thinking like a lawyer. "Teachers are not agreed on the relative emphasis to put on each of these approaches," Bowker noted. "It is sufficient here to say that the student should be aware of both." ${ }^{181}$ Not terribly inspiring or particularly innovative, but as straightforward a summary of North American legal education for most of the past 50 years as exists.

The Minnesota Law School had arrived at a remarkably similar destination, as the Minnesota Plan's ambition became dulled with time and experience. Fraser's retirement in 1948 ushered in the deanship of Maynard Pirsig who maintained the Minnesota Plan's broad objectives and four-year system. Pirsig's replacement, William Lockhart, once a proponent of the Minnesota Plan, ${ }^{182}$ began his deanship in 1956 by reverting to the more traditional three-year law degree. ${ }^{183}$ After the Second World War, statism became the watchword and defining feature of the new Soviet enemy, and the ideal of service to the state - as opposed to the individual — lost much of its moral and ideological force. ${ }^{184}$ Weakened as rhetoric, the Minnesota Plan could not withstand the loss of its architect and loyalists. Probably the die had been cast with Fraser's retirement, but Read's departure for Dalhousie's deanship in 1950 and Riesenfeld's return to Berkeley in 1952 removed the figures most strongly associated with the Minnesota Plan. ${ }^{185}$ In Fraser's absence, the Minnesota faculty's previously silent dissenters made their opposition to the Minnesota Plan more strongly known. "[L]aw school training must be geared to turn out efficient practitioners," Professor David Louisell argued, meaning less political science, economics, and history and more hard doctrinal law. ${ }^{186}$ Student complaints about the fourth year "of boredom" and faculty opposition - why must Minnesota accomplish in four years what other elite law schools managed to do in three? - sealed its fate. ${ }^{187}$ Four-year programs in other American law schools similarly shed the additional year of study. Fraser watched it all unfold from San Francisco, where, for the final 15 years of his career, he taught property law at Hastings College of Law. ${ }^{188}$

\footnotetext{
Ibid at 221 .

Ibid at 222 .

Ibid.

Ibid.

William B Lockhart, “The Minnesota Program of Legal Education: The Four-Year Plan” (1950) 3:2 J Leg Educ 234.

Stein, supra note 83 at 194-96.

See generally Mary L Dudziak, Cold War Civil Rights: Race and the Image of American Democracy (Princeton: Princeton University Press, 2000).

185 Pirsig knew it. "Mr. Read's leaving would be a serious loss to the law school," he pleaded to the University's President, "particularly at this juncture, and, as I view it, a mistake for him personally. But, as of the present moment, the prospect of convincing him of this does not look good." Pirsig to Morrill (27 February 1950), Minneapolis, University of Minnesota Archives (Law School Papers, 413, Box 10). Louisell to Pirsig (1 April 1952), Minneapolis, University of Minnesota Archives (Law School Papers, 413, Box 10).

Pirsig Interview, supra note 97.

The Ottawa Citizen found Fraser in February 1951 taking in a Californian exhibit of Canadian art. Charles A Bowman, "Canadian Art in California: Gallery Throng Enjoys Documentary Films," Ottawa Citizen (17 February 1951) 11.
} 
Without the driving force of Fraser's commitment to innovation and a public service orientation, Minnesota entered the second half of the twentieth century largely replicating the curriculum, culture, and approach of America's other leading law schools. Indeed, as Laura Kalman elaborates, at Yale and Harvard too, convergence in methods, curricula, and underlying objectives typified American legal education in the 1950s. ${ }^{189}$ And yet law schools had changed. The Minnesota Plan's legacy lived on in the law school curriculum in various hidden ways: the permanence of public law and contemporary legal theory in a much expanded curriculum; a tempered sense that broader obligations to the administration of justice play a role in the purpose of legal education; the faith, perhaps misguided, that law professors can teach everything and anything; the unshakeable belief in the societal power of lawyers and law.

In the end, the innovations exemplified by Fraser's Minnesota Plan resulted in a large degree of convergence in legal education on both sides of the border. Canadian legal academics continued to watch American developments closely, and continuing personal ties between institutions solidified that influence. In addition to Minnesota's influence on Bowker, Read brought Fraser's imprint back across the border on returning to Dalhousie. Instigating what he termed "the Weldon tradition," Read argued that the purpose of Dalhousie Law School would be to produce not only great lawyers but also "statesmen" dedicated to "high academic and professional standards and unselfish public service."190 Read chose, for understandable reasons, to root that ethic in Dalhousie's own past, but it was a vision of legal education that bore a remarkable similarity to that of Minnesota's. Spread further by informal bonds of friendships and the formal network of the Canadian Association of Law Teachers, ideas about legal education moved easily and rapidly among Canada's exclusive enclave of male law professors.

At CALT's annual meeting in 1954 in Winnipeg, attendees heard from Professor Shelden Elliott of New York University Law School, and former executive of the AALS, that " $[\mathrm{t}] \mathrm{he}$ trend to public law has been to some extent reversed and there is now more emphasis on private law." ${ }^{\prime 11}$ For Bowker, the lessons were obvious: "To those who want law schools to do everything, except possibly what they do now, we can point to the American experience to show that many innovations are not lasting and that there is no simple, ready-made recipe for producing model practitioners." 192 Maxwell Cohen went one step further. "I take it," he stated, "there will be agreement among us — bench, bar and law teachers — that we share the same generalized views about the ends of a law school and a legal education." 193 "A law school, and the education it provides," Cohen asserted, "must train lawyers to practise law." 194 But he buttressed the prosaic nature of the claim with the Poundian flourish (and citation) that a proper legal education must take account of law's essentially dual character

Kalman, supra note 6. See especially ibid, ch 6 at 188-228.

Willis, History of Dalhousie Law, supra note 6 at 257, 8-10.

WF \& Alex Smith, "The Law Teachers' Annual Meeting" (1954) 32:6 Can Bar Rev 659 at 661. Elliot also maintained that "[ $[$ the expansion of seminars has passed its peak. Legal writing may have been overemphasized" (ibid).

Ibid.

Maxwell Cohen, "Objectives and Methods of Legal Education: An Outline" (1954) 32:7 Can Bar Rev 762 at 762 [Cohen, "Objectives and Methods"].

Ibid at 763 . 
as "a working social tool to maintain order" and "a running commentary on the values held by that society." 195 Accordingly,

no legal education can be said to be an education about the law that does not provide the student with an awareness of the sources and the nature of the rules as well as an awareness of the legal system as a whole. The law is both philosophy and social engineering. The law is art and analysis. The law is history and logic. The law is form and substance. ${ }^{196}$

Although some law schools balanced these elements somewhat differently, usually accordingly to the particular proclivities of its dean or the interest and expertise of its available law teachers, an inexorable consensus had emerged, one whose gravitational pull proved even too mighty for the Ontario bar to continue to resist. ${ }^{197}$ "We are moving slowly but surely," Cohen concluded, "toward maturity in legal education in Canada."198 It was a maturity that looked remarkably similar to university-based legal education in the United States.

The transfer of ideas is always one of adaptation rather than adoption, and certainly Bowker's own experiences of legal practice, close ties to the profession, and, frankly, dependence on lawyers to make the Faculty of Law function, softened the distinctions between public and private service that caused Fraser so much concern. But Bowker forever considered himself a Minnesota product, Pirsig remained a lifelong friend, and his experiences of American legal thinking produced in his teaching and deanship a blended balance of private and public law, client and state orientations, theory and practice. At the University of Alberta, Faculty of Law, as elsewhere, to greater and lesser extents according to the course and professor teaching it, sociological jurisprudence, legal realism, political context, and law and society all became subsumed within the existing teaching structures, curricular offerings, and educational theories of legal education.

In his nearly 20 year career as dean at the University of Alberta, Faculty of Law, Wilbur Bowker was famous for his frequent rendition, from memory, of Ernest Thayer's poem, Casey at the Bat. ${ }^{199}$ Evidence of his gifted memory, his love of the great American pastime, and a slight eccentricity, Bowker delighted in performing the comedic tale of heroic Casey's insouciant plate appearance, the game on the line. But Casey, as everyone knows, strikes out, and there is no joy in Mudville. It was easy for Bowker to revel in the poem's ecstasy of dashed hopes and crushed disappointments since, from one perspective, his professional career had witnessed little of either. His unlikely professorship had turned into an unlikely deanship of remarkable longevity and success. He retired from the deanship in 1968, deeply and widely admired across the profession, but nonetheless "glad to leave the headaches of admissions, recruiting, curriculum and endless committee meetings to others." ${ }^{200}$ But Bowker experienced strikes at the plate too. His legal scholarship, although broad-ranging and competent, did not define him or carve a lasting legacy in the legal literature. His hoped for $\mathrm{Ph}$.D. never materialized when he failed to convert his sabbatical year at Yale into a

Ibid.

Ibid [emphasis in original].

Kyer \& Bickenbach, supra note 6.

Cohen, "Objectives and Methods," supra note 193 at 768.

Ernest L Thayer, "Casey At the Bat," The Daily Examiner (3 June 1888) 4.

Bowker to Read (26 January 1968), Halifax, Dalhousie University Archives (Read Papers). 
workable dissertation, and he never published the great synthesis of Alberta's legal history as he had planned. But he did shape a law school and with it a generation of lawyers and a provincial legal culture along with them, as symbolized in the provincial government justice building which bears his name.

Although Bowker never fully embraced the most ambitious aspects of the Minnesota Plan's innovations, his time across the border left its imprint on his legal thinking about rights, his skepticism of judicial review, and his view of a legal education that combined public law orientation with private law fundamentals. Bowker's law faculty emphasized professionalism, diligence, idealism, and the responsibilities and camaraderie of professional standing. In doing so, it epitomized a Canadian consensus among common law schools on legal education that came to dominate and define university-based law schools across the country. Despite the sorrow in Casey's Mudville, the poem notes that somewhere "in this favored land the sun is shining bright; / The band is playing somewhere and somewhere hearts are light, / And somewhere men are laughing, and somewhere children shout." ${ }^{201}$ As dean at the University of Alberta, Faculty of Law for nearly 20 years, that somewhere is where Bowker spent the bulk of his legal career.

\section{Conclusions}

"The history of legal education in this country is the history of salutary movements that missed the point," Robert Hutchins, President of the University of Chicago, and former Dean of Yale Law School, declared to a gathering of New York lawyers in 1937. ${ }^{202}$ Harvard's famous case method, Hutchins argued, had "infused life into legal education," but at the expense of sacrificing overarching legal principles. ${ }^{203}$ The "functionalist" movement, he lamented, had similarly overshot the target by placing undue emphasis on "what the lawyer does," instead of "what the lawyer is," or could be. ${ }^{204}$ Law, Hutchins explained, provided "a set of political determinations of the principle of justice," at once the product of both quotidian "practical reason" and aspirational conceptions of the common good. ${ }^{205}$ Accordingly, he concluded,

legal education must consist of the study of law as it is and operates, the study of how law came to be what it is, and the study of the principles which must be employed to solve the problem of what the law ought to be. Not the study of the cases alone, nor the study of how the law operates in fact, nor the study of legal philosophy will give us a legal education. We must have all three. ${ }^{206}$

The future of legal education envisioned by Hutchins was the precise destination of a watered-down Minnesota Plan. Like the culmination of so many other innovations in legal education, the moment of searching was ultimately one of retention, absorption, and balance.

Thayer, supra note 199.

Robert Maynard Hutchins, "Legal Education" (1937) 4:3 U Chicago L Rev 357 at 357.

Ibid.

Ibid at 362. "Because theory was being badly and unrealistically taught," Hutchins elaborates, "[the realists] objected to theory itself. They proposed substitutes for it that led to the still further degradation of jurisprudence and of legal education; and the realism they achieved was ... a realism in name only. What they should have done was to recognize that jurisprudence is central and to revive the intelligent study of it" (ibid at 364).

Ibid at 364-65.

Ibid at 368 . 
Several of the major structural, institutional, curricular, and pedagogical elements established in the late nineteenth century would continue - a three-year university-based program consisting of the fundamentals in private law taught with appellate cases. Blended into that model were innovations - public law courses recognizing the centrality of legislators and statutes, extra-legal perspectives and materials in history, philosophy, political science, economics, and psychology found their place in course materials, and teaching practices and assignments that called upon law students to fashion larger societal solutions out of the raw materials of law. A good legal education in the postwar era had to do all of those things in recognition of the power, scope, and potential of law.

If Canadian legal education had similarly come of age, it had done so in the crucible of postwar economic expansion, an expanding role for government in everyday life, and a border crossing consensus fostered among North American law teachers not only about legal norms and the administrative state, but about the purpose and techniques of legal education. ${ }^{207}$ The working assumption in Canadian and American literatures alike has been that directions in legal education emanated outwards (and northwards) from an American wellspring (usually traced to Harvard and Yale). Yet Everett Fraser and the Minnesota Plan remind us that influential ideas about legal education and the personalities that crafted them travelled in both directions across the Canadian and American border, and took shape in institutions and contexts often overlooked. Although he obtained American citizenship in 1919, Fraser never lost the imprint of the immigrant experiences of thinking otherwise. His nation of origin does not account for Fraser's work ethic, singular dedication in the pursuit of an idea, and forceful manner, but his Canadian roots, conservative admiration for British constitutionalism, and emigration did encourage fluid and creative thinking across and beyond entrenched methods. It is perhaps no accident that of the Minnesota Plan's principal architects — Fraser, Read, Riesenfeld, and Pirsig — only the latter was raised in the United States. The Minnesota Plan crossed borders too. It was carried back to Canada by Horace Read, teaching legislation to generations of Canadian law students, and in Dalhousie's revived Weldon Tradition. ${ }^{208}$ And it came back with Wilbur Bowker - in his commitment to broaden curricular horizons in preparing students for professional life in an era of the expanding state, but mostly in his belief in the power of legal education to make a better world.

If Fraser and Bowker signalled the beginning of one era in legal education, they equally partook in the ending of another. As essentially lifelong deans, they personified their respective institutions and fashioned law schools in symmetry with their values, visions,

On the depth of the consensus among Canadian legal scholars of the period, see Girard, "Who's Afraid," supra note 75 at 731 :

These scholars shared post-Diceyan ideas about the respective roles of the state, courts, administrative agencies, markets, and the common law; the existence and maintenance of the public-private divide; the necessity of advancing civic equality; and the role of universities in creating a corps of professional experts who would assume important leadership roles in all spheres of life. Their heroes were Oliver Wendell Holmes, Felix Frankfurter, Benjamin Cardozo, Roscoe Pound, and, in Canada, Ivan Rand. In short, this set of ideas might be described as a Canadianized version of New Deal liberalism, undergirded by a strong commitment to functionalism as a legal and administrative ideal.

WH Charles to Ronald Macdonald (21 August 1991), Halifax, Dalhousie University Archives (Read Papers). Read adopted something of Fraser's decanal style too. Charles remembered Read as being "of the old school and autocratic in that sense. I do not recall there being too many committees at work during my time as a member of the faculty with Dr. Read as dean" (ibid). 
attributes, and deficiencies. Constrained, of course, by budgets, university administrations, and the demands of the profession, they nonetheless exercised near total control for more than two decades over the admissions, staffing, curricula, and culture of their law schools. As universities and their governance structures expanded in the post-war era, as the law school's traditional claims to autonomy and distinctiveness eroded, so did the practice of hiring deans for life, and some of the idiosyncrasies and freedoms such life tenures entailed. Yet it is in Fraser and Bowker - two border-crossing law school deans for life, and the law school lives of these two deans - that this article finds the emergence of modern North American legal education. The point is not that such developments were not happening elsewhere - they were. Nor is the argument that legal education would have looked very different if Fraser and Bowker had decided, as young men, to study medicine - it would not. The claim is rather that Fraser and Bowker reflect and represent the border crossing innovations and conservations that marked and defined a critical era in the making of modern legal education. We still teach and learn the law in the traces, imprints, and shadows they left behind. 